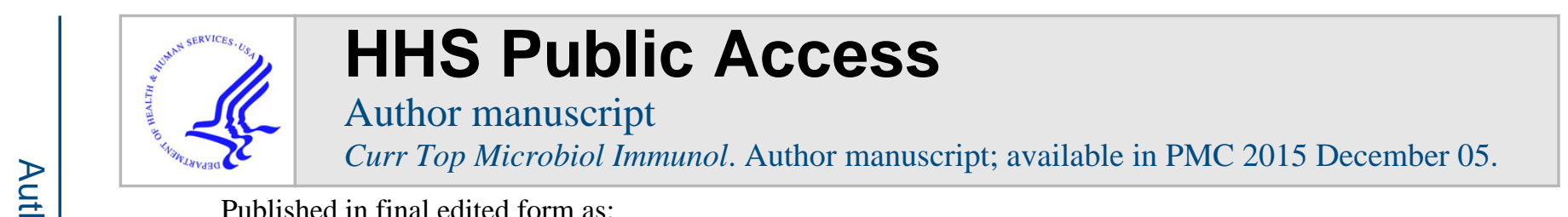

Published in final edited form as:

Curr Top Microbiol Immunol. 2015 ; 390: 211-240. doi:10.1007/978-3-319-22822-8_9.

\title{
Infectious Mononucleosis
}

Samantha K. Dunmire,

Center for Immunology, University of Minnesota, Minneapolis, MN 55455

Kristin A. Hogquist, and

Center for Immunology, University of Minnesota, Minneapolis, MN 55455

Henry H. Balfour Jr.

Department of Laboratory Medicine and Pathology, Department of Pediatrics, University of Minnesota, University of Minnesota Medical School, Minneapolis, MN 55455

Samantha K. Dunmire: dunmi002@umn.edu; Kristin A. Hogquist: hogqu001@umn.edu; Henry H. Balfour: balfo001@umn.edu

\begin{abstract}
Infectious mononucleosis is a clinical entity characterized by sore throat, cervical lymph node enlargement, fatigue and fever most often seen in adolescents and young adults and lasting several weeks. It can be caused by a number of pathogens, but this chapter only discusses infectious mononucleosis due to primary Epstein-Barr virus (EBV) infection. EBV is a $\gamma$-herpesvirus that infects at least $90 \%$ of the population worldwide. The virus is spread by intimate oral contact among teenagers and young adults. How preadolescents acquire the virus is not known. A typical clinical picture with a positive heterophile test is usually sufficient to make the diagnosis, but heterophile antibodies are not specific and do not develop in some patients. EBV-specific antibody profiles are the best choice for staging EBV infection. In addition to causing acute illness, there can also be long-term consequences as the result of acquisition of the virus. Several EBV related illnesses occur including certain cancers and autoimmune diseases, as well as complications of primary immunodeficiency in persons with the certain genetic mutations. A major obstacle to understanding these sequelae has been the lack of an efficient animal model for EBV infection, although progress in primate and mouse models has recently been made. Key future challenges are to develop protective vaccines and effective treatment regimens.
\end{abstract}

\section{Introduction}

Infectious mononucleosis is a clinical entity characterized by sore throat, cervical lymph node enlargement, fatigue and fever. It can be caused by a number of pathogens, but this chapter considers it as disease resulting from primary Epstein-Barr virus (EBV) infection and is focused on the immunocompetent host. Infectious mononucleosis was the name coined by Sprunt and Evans (Sprunt 1920) to describe a syndrome that resembled an acute infectious disease accompanied by atypical large peripheral blood lymphocytes. These atypical lymphocytes, also known as Downey cells (Downey 1923), are actually activated CD8 T lymphocytes, most of which are responding to EBV-infected cells. Infectious mononucleosis is medically important because of the severity and duration of the acute illness and also because of its long-term consequences especially the development of certain cancers and autoimmune disorders. 


\section{Epidemiology of Primary EBV Infection}

\subsection{Age-specific Prevalence of EBV Antibodies}

EBV infection is extremely common worldwide and approximately $90 \%$ of adults become antibody-positive before the age of 30 (de-The et al. 1975; Venkitaraman et al. 1985; Levin et al. 2010). A recent example is that 1037 (90\%) of 1148 subjects 18 and 19 years old participating in the U.S. National Health and Nutrition Examination Surveys (NHANES) between 2003 and 2010 had IgG antibodies against EBV viral capsid (VCA) antigen, indicative of prior infection (Balfour et al. 2013).

The prevalence of EBV antibodies in preadolescent children is lower, varying from $20 \%$ to $80 \%$ depending on age and geographic location. Factors clearly related to early acquisition of primary EBV infection include geographic region (reviewed in (Hjalgrim et al. 2007), and race/ethnicity (Balfour et al. 2013; Condon et al. 2014). Other factors implicated are socioeconomic status (Henle et al. 1969; Hesse et al. 1983; Crowcroft et al. 1998), crowding or sharing a bedroom (Sumaya et al. 1975; Crowcroft et al. 1998), maternal education (Figueira-Silva and Pereira 2004), day care attendance (Hesse et al. 1983), and school catchment area (Crowcroft et al. 1998).

Regarding race/ethnicity, it was recently shown that antibody prevalence across all age groups of U.S. children 6 to 19 years old enrolled in NHANES between 2003 and 2010 was substantially higher in non-Hispanic blacks and Mexican Americans than non-Hispanic whites (Balfour et al. 2013). The greatest disparity in antibody prevalence was among the younger children, especially the 6- to 8-year-olds. Interestingly, the difference in antibody prevalence between whites and non-whites diminished during the teenage years. Thus, family environment and/or social practices may differ among white and non-white families, which could account for this disparity in antibody prevalence in younger children. Within each race/ethnicity group, older age, lack of health insurance, and lower household education and income were statistically significantly associated with higher antibody prevalence.

These NHANEs findings were confirmed (Condon et al., 2014) and extended to include younger children (18 months to 6 years of age) living in the Minneapolis-St. Paul metropolitan area. The Twin Cities study showed that the divergence in age-specific antibody prevalence between blacks and whites was clearly apparent by the age of 5 years.

The age at which primary EBV infection is acquired may be increasing in developed countries (Morris and Edmunds 2002; Takeuchi et al. 2006; Balfour et al. 2013). This is important to monitor because there is a complex interplay between age of acquisition, symptomatic versus asymptomatic infection, and the subsequent risk of EBV-associated cancers or autoimmune diseases. For example, younger age at the time of primary EBV infection among Kenyan infants was associated with elevated levels of EBV viremia throughout infancy, leading the investigators to postulate that these infants were at higher risk for endemic Burkitt lymphoma (Piriou et al. 2012; Slyker et al. 2013). Another study found that Greenland Eskimo children acquired primary EBV infection at an earlier age and had higher titers of IgG antibody against VCA than age-matched Danish children (Melbye et 
al. 1984). The authors speculated that early infection with "a large inoculum of EBV" explained why Eskimos were at high risk for nasopharyngeal carcinoma versus Danes who were not. Nevertheless, late acquisition of primary EBV infection is also detrimental in several contexts. Adolescents and young adults are more likely to experience infectious mononucleosis during primary infection than children (Krabbe et al. 1981). Furthermore, multiple sclerosis (MS) is an inflammatory autoimmune disease that involves EBV infection and risk of MS is higher amongst individuals who have experienced infectious mononucleosis (Ascherio and Munger 2010). Infectious mononucleosis also increases the risk of Hodgkin's lymphoma (Hjalgrim et al. 2000). Thus, since age of primary EBV infection is an important factor in infectious mononucleosis, it is an important consideration for EBV related diseases.

\subsection{Routes of Transmission of Primary EBV Infection}

Kissing is the major route of transmission of primary EBV infection among adolescents and young adults. This was elegantly documented by Hoagland's careful clinical observations (Hoagland 1955) and confirmed many decades later by a prospective study at the University of Minnesota (Balfour et al. 2013). Penetrative sexual intercourse has been postulated to enhance transmission (Crawford et al. 2006), but we have found that subjects reporting deep kissing with or without coitus had the same risk of primary EBV infection throughout their undergraduate years (Balfour et al. 2013).

The incubation period of infectious mononucleosis is approximately 6 weeks. Hoagland's clinical records suggested an incubation period of 32-49 days based on the dates of kissing episodes until the onset of infectious mononucleosis (Hoagland 1955). A well-documented case was reported by Svedmyr et al. (1984) in which the kissing event occurred 38 days prior to onset of symptoms (Svedmyr et al. 1984). Behavioral data from our medical history questionnaires collected during prospective studies are consistent with an incubation period of 42 days (Balfour et al. Unpublished observations).

Besides deep kissing, primary EBV infection can also be transmitted by blood transfusion (Gerber et al. 1969), solid organ transplantation (Hanto et al. 1981), or hematopoietic cell transplantation (Shapiro et al. 1988), but these routes account for relatively few cases overall. Alfieri et al. (1996) used polymorphisms in the EBV BAMHI-K fragment length and size polymorphisms in EBV nuclear antigen (EBNA) -1, -2 and -3 proteins to identify the specific blood donor responsible for transmitting EBV to a 16-year-old liver transplant recipient who subsequently developed infectious mononucleosis.

The way young children contract EBV is unknown. A reasonable supposition is that they are infected by their parents or siblings who are "carriers" of the virus and who intermittently shed it in their oral secretions (Sumaya and Ench 1986). An extreme example of this is the very early acquisition of EBV among three distinct Melanesian populations whose infants have multiple caregivers that premasticate the baby's food (Lang et al. 1977). 


\section{Clinical Manifestations of Primary EBV Infection}

\subsection{Acute IIIness}

Our prospective studies have determined that $75 \%$ of young adults between the ages of 18 and 22 develop typical infectious mononucleosis after primary EBV infection.

Approximately $15 \%$ have atypical symptoms and $10 \%$ are completely asymptomatic (Balfour et al. 2013); Balfour et al. Unpublished observations). There are two common presentations among symptomatic patients. The first is the abrupt onset of sore throat, which many patients say is the worst sore throat they have ever had. Patients may also notice a swollen neck that results from cervical lymph node enlargement. Parenthetically, anterior and posterior cervical nodes are usually equally enlarged. The second common presentation is the gradual onset of malaise, myalgia ("body aches") and fatigue. Table 3.1 shows the frequency of signs and their median duration in 72 undergraduate students studied prospectively. Most findings have a median duration of 10 days or less but fatigue and cervical lymphadenopathy persist for a median of 3 weeks. Other findings, seen in fewer than $20 \%$ of cases in our experience, include abdominal pain, hepatomegaly, splenomegaly, nausea, vomiting, palatal petechiae, periorbital and eyelid edema, and rash. Rash is seen more often in patients given penicillin derivatives, which is most likely due to transient penicillin hypersensitivity (Balfour et al. 1972).

Subclinical hepatitis documented by elevated levels of alanine aminotransferase occurs in approximately $75 \%$ of prospectively followed patients and, in some cases (5-10\%), overt hepatitis develops with tender hepatomegaly and jaundice (Balfour et al. Unpublished observations).

Primary EBV infection in preadolescents has not been thoroughly investigated most likely because prospective studies in young children are logistically difficult to conduct. The assumption has been that the majority of primary EBV infections in children before puberty are asymptomatic but that is not necessarily so. Young children, especially those under the age of 4 years, may not develop a positive heterophile antibody response during primary EBV infection (Horwitz et al. 1981) and unless specific EBV assays are performed, the diagnosis will be missed.

\subsection{Complications of the Acute IIIness}

Fortunately, serious complications during the acute phase of primary EBV infection are rare. Table 3.2 shows reported complications divided into those estimated to occur in at least $1 \%$ of patients and those that are seen in fewer than 1\% of cases (Hoagland and Henson 1957; White and Karofsky 1985; Robinson 1988; Connelly and DeWitt 1994; Jenson 2000). Splenic rupture is the most feared complication, which has kept many athletes out of competition for weeks. Current consensus is that athletes may return to contact sports 3 weeks after onset of infectious mononucleosis provided they are afebrile, their energy has returned to normal, and they have no other abnormalities associated with primary EBV infection (Putukian et al. 2008).

Although most symptoms associated with infectious mononucleosis resolve in a matter of months, there can be severe and lasting disease that develops following primary EBV 
infection. One of these complications may manifest in the form of chronic active EBV (CAEBV). Patients presenting with CAEBV generally exhibit signs that can occur during infectious mononucleosis such as fever, lymphadenopathy, splenomegaly and hepatitis, and show markedly elevated levels of EBV DNA in the blood (Kimura et al. 2001). Less frequently, patients may also present with lymphoma or hemophagocytic disease, a complication of EBV that is discussed in greater detail below (Kimura et al. 2003). Interestingly, in many cases of CAEBV outside of the United States, particularly in Japan, EBV is reported to infect T or NK cells rather than its usual reservoir of B cells (QuintanillaMartinez et al. 2000; Kimura et al. 2001). Several instances of B cell tropic CAEBV have also been reported, but these fall into the minority of documented incidences (Schooley et al. 1986; Kimura et al. 2003). While some patients have T or NK cell dysfunction, none of the subjects in a National Institutes of Health (NIH) study had mutations typically associated with EBV related immunodeficiencies and thus the disease observed in that study was considered to be largely insidious. The most successful treatment for CAEBV has been hematopoietic stem cell transplant. In the same NIH study, all but one of the patients who presented with CAEBV died within an average of six years unless a transplant was received. Those that survived all subsequently became negative for EBV DNA in the blood (Cohen et al. 2011).

EBV may also cause hemophagocytic disease, which is alternately referred to in the literature as EBV-associated hemophagocytic syndrome or EBV-associated hemophagocytic lymphohistiocytosis (HLH). The relative rarity of any form of HLH stands as a barrier to diagnosis, and thus cases of EBV-HLH are even more uncommon. The disease is characterized by fever, splenomegaly and cytopenias, though the key laboratory signs are high levels of ferritin and soluble CD25 (Jordan et al. 2011; Janka 2012). The distribution of EBV-HLH seems to be similar to CAEBV, focused mainly in Asian populations and infecting T or NK cells in those groups (Kawaguchi et al. 1993) though B cells are also infected in other populations (Beutel et al. 2009). EBV-HLH may be related to one of several primary immunodeficiencies discussed below, but EBV infection may be a triggering event even in the absence of an identified genetic condition. Interestingly, transcriptome profiling studies showed that the peripheral blood gene expression signature observable during infectious mononucleosis highly resembles that of HLH (Dunmire et al. 2014). This reinforces links between primary EBV infection as a trigger in the initiation of HLH.

$\mathrm{X}$-linked lymphoproliferative syndrome (XLP) is a disease characterized by anemia, hypergammaglobulinemia and lymphohistiocytosis. Generally the boys who present with this disease exhibit massive cellular responses to primary EBV infection that result in hemophagocytic pathology, even though they are simultaneously unable to control EBV transformed B cells (Cannons et al. 2011). It was discovered that the main deficiency involved with XLP is in the signaling lymphocytic activation molecule associated protein (SAP), which is encoded by the human gene SH2D1A. Mutations in this gene disrupt the ability of T cells and NK cells to interact with B cells, resulting in a lack of immunoglobulin class switching and meaning that $\mathrm{T}$ cells and NK cells cannot efficiently recognize $\mathrm{B}$ cell targets to induce death (Hislop et al. 2010; Zhao et al. 2012). 


\subsection{EBV associated diseases}

EBV has been shown to be the causative agent of about one percent of the worldwide human cancer burden. In particular, EBV infection is associated with neoplasia of lymphoid and epithelial origins including endemic Burkitt's lymphoma (eBL) and Hodgkin's lymphoma (HL) in the case of the former, as well as nasopharygeal carcinoma and gastric carcinoma in the case of the latter. EBV is considered the etiologic agent in $95 \%$ of cases of eBL, which occur in regions where malaria is common (Brady et al. 2007). Likewise, EBV can be detected in a high proportion of HL cases in underdeveloped nations, but accounts for less than half of cases in Western countries (Flavell and Murray 2000). It is important to note that incidence of infectious mononucleosis is exceptionally low in Southeast Asia and equatorial Africa where EBV infection during childhood is nearly ubiquitous, thus it might be extrapolated that infectious mononucleosis does not have a strong correlation with either eBL or HL in these areas (de-The et al. 1978). Emerging evidence suggests that previous presentation with infectious mononucleosis can increase the risk of HL (Hjalgrim et al. 2000). While associations between infectious mononucleosis and epithelial carcinomas have not been explored, the presence of EBV in tumors from nasopharyngeal and gastric carcinoma patients is well documented. About $10 \%$ of human gastric carcinomas are EBV positive (Iizasa et al. 2012). Like eBL and HL seen in underdeveloped nations, nasopharyngeal carcinomas from endemic regions are virtually all positive for EBV DNA (Raab-Traub 2002), with these tumors thought to be derived from a single EBV infected epithelial cell (Raab-Traub and Flynn 1986; Pathmanathan et al. 1995).

It is possible that achieving a very high viral titer in the blood at any point in life predisposes individuals to subsequent EBV related cancers. For example, patients who present with eBL and endemic nasopharygeal carcinomas live in malaria endemic areas. Evidence shows that patients being treated for malarial disease can have extremely high titers of EBV in the blood (Nijie, 2009). Titers of this magnitude are seen exclusively in patients presenting with infectious mononucleosis in developed countries. Thus, it may be possible to reduce occurrences of cancer with prophylactic or therapeutic vaccines aimed at preventing primary EBV infection or at the very least reducing the set point at which the virus is maintained in these individuals.

In recent years, infectious diseases have been emerging as possible triggers for autoimmune disorders. EBV infection in particular has come to be highly associated with occurrence of MS. EBV as a causation factor in MS was first proposed over thirty years ago (Warner and Carp 1981). Many correlative observations for this trend exist, including a low incidence of infectious mononucleosis and MS in developing countries, and MS usually first manifests after the adolescent years during which EBV would be acquired, increasing at a rate of $11 \%$ per year following primary EBV (Ascherio and Munger 2010). There is also a high association between patients who recall having infectious mononucleosis and subsequent development of MS (Alotaibi et al. 2004; Pohl et al. 2006; Banwell et al. 2007). Furthermore, MS in EBV negative individuals occurs very infrequently (Levin et al. 2010; Pakpoor et al. 2013).

A causative role for EBV was supported by examination of the antibody profiles of patients with MS, scrutinizing the viral loads, epitope specificity, and quantity of antibodies, 
especially those against EBNA. The risk of MS increases positively with levels of circulating anti-EBNA antibodies (Ascherio et al. 2001; DeLorenze et al. 2006; Levin et al. 2005; Sundstrom et al. 2004.) The ability to discriminate MS cases and controls was substantially enhanced by the inclusion of quantitative measures of the anti-EBNA-1 response to EBV infection (Strautins et al. 2014). Interestingly, the strong genetic association of MS with particular human leukocyte antigen (HLA) alleles primarily reflects the association with anti-EBV responses (Rubicz et al. 2013). Researchers recently treated an MS patient with autologous T cells expanded by exposure to EBV antigens. Transfer of the EBV specific CD8 T cells resulted in a decrease in anti-EBV antibody as well as the size and number of MS related lesions in the brain (Pender et al. 2014).

\section{Virus-Host Interactions during Primary EBV Infection}

\subsection{Incubation Period}

The long incubation period of EBV continues to be poorly understood due to a lack of samples obtained between the time of infection and presentation with EBV related symptoms. During primary infection, viral replication is first detected in the oral cavity (Balfour et al. 2013). The virus infects tonsillar epithelial cells as well as B cells in the parenchyma of the tonsil (Wang et al. 1998). There may be a cyclic nature to the pattern of infection in the oral cavity as it has been shown in vitro that virus derived from epithelial cells has a much higher entry efficiency for infecting B cells and vice versa, resulting a switched viral tropism depending on the cell type in which the virus replicates (Borza and Hutt-Fletcher 2002). At some point during the incubation period, the virus moves from the oral cavity to the blood. Little is known about the kinetics or means of this transition. A type I interferon response was detected by gene expression profiling approximately 2 weeks prior to symptom onset in some subjects experiencing primary EBV infection (Dunmire et al. 2014). Viral genomes can sometimes be detected in the peripheral blood as early as three weeks prior to symptom onset and consistently at least one week prior to illness (Dunmire et al. unpublished observations), where it is probably maintained latently in resting memory phenotype B cells (Hadinoto et al. 2008).

\subsection{Acute Infection}

The kinetics of the EBV viral loads and EBV-specific antibody responses during primary EBV infection are illustrated in Figures 1 and 2. High viral loads in both the oral cavity and blood are detected around the time of symptom onset in infectious mononucleosis and accompanied by production of IgM antibodies to EBV VCA and an extraordinary expansion of CD8 T lymphocytes (Balfour et al. 2013). While CD8 T cell responses during primary EBV infection have been thoroughly discussed elsewhere (Hislop et al. 2007; Odumade et al. 2011), a brief discussion of CD8 T cell and B cell responses follows. Of particular interest is the response of cytotoxic CD8 T cells, which have been shown to be important in the control of EBV infected B cells as evidenced by the disease that occurs in patients who lack elements of CD8 $\mathrm{T}$ cell function such as the ability to interact with and kill infected B cells (Rigaud et al. 2006; Palendira et al. 2011). 
During infectious mononucleosis when there are very high numbers of circulating CD8 T cells, many of these cells are EBV specific and directed toward lytically expressed proteins from the immediate early and early stages of the lytic cycle with particular predilection for the immediate early. Cells specific for some late antigens tend to emerge only after the patient has been infected for some time as discovered by generating $\mathrm{T}$ cell clones from infectious mononucleosis patients (Abbott et al. 2013). The case of latency, however, is rather different and is often dependent on the relevant HLA type of the EBV infected individual in question. Immunodominant epitopes for the most prevalent HLA types generally include those derived from latently expressed proteins, especially EBNA-2 and EBNA-3, although some patients develop a strong population of CD8 T cells specific for less readily expressed antigens such as EBNA-1 (Blake et al. 2000; Hislop et al. 2007).

Both CD8 and CD4 T cells require cell-to-cell contact in order to become activated and perform related functions (Adhikary et al. 2007; Merlo et al. 2010). Although total CD4 numbers do not increase appreciably during infectious mononucleosis, evidence exists to support the concept that CD4 T cells are activated and help control infected B cells. Using major histocompatability complex (MHC) II tetramers, it was shown that several lytic antigens are recognized by CD4 $\mathrm{T}$ cells during acute infection and that these cells are maintained at low levels in the blood of EBV infected hosts (Long et al. 2013). That study also revealed that the response to different antigens varies: $\mathrm{CD} 4(+) \mathrm{T}$ cell responses to EBNA1 did not develop until much later, which likely explains the delay in EBNA1 IgG antibody responses.

Natural killer (NK) cells are also emerging as important players during infectious mononucleosis. Several immunodeficiences involving T and NK cells and/or their cytolysis pathways result in severe EBV related outcomes (Menasche et al. 2005; Parvaneh et al. 2013). These include familial hemophagocytic lymphohistiocytosis 2 (FHL2), $x$-linked lymphoproliferative syndrome (XLP), XIAP deficiency, and x-linked immunodeficiency with $\mathrm{Mg}+2$ defect (XMEN) disorders, and are discussed in detail in another chapter of this book. The value of NK cells specifically, was suggested by the observation that NK cells preferentially killed EBV infected cells as the virus entered the lytic cycle (Pappworth et al. 2007). The role of NK cells in vivo was investigated using a humanized mouse model, where NOD-scid $\gamma$ c-/- (NSG) mice were reconstituted with CD34+ lin- hematopoietic stem cells (Strowig et al. 2010; Ramer et al. 2011) and infected with the B95.8 strain of EBV and monitored for signs of infectious mononucleosis such as CD8 lymphocytosis and viremia. Animals depleted of NK cells experienced more severe EBV related disease (Chijioke et al. 2013). It is interesting to note that NK depletion after an established EBV infection did not have significant effects, in contrast to the effect of depletion before infection. Given the gap in the robustness of responses observed between tonsillar and peripheral blood NK cells, it is possible that peripheral NK cells during the systemic infectious mononucleosis phase are less important than those during early infection in the oropharynx (Strowig et al. 2008). Indeed, studies in humans have disagreed about the state of NK cells in peripheral blood during infectious mononucleosis. Work from Williams et al. showed an inverse correlation between NK cell numbers in the periphery and virus in the blood (Williams et al. 2005). In contrast, a larger prospective study found a positive correlation (Balfour et al. 2013). Thus, 
the interplay between NK cells and blood virus in human subjects needs further study. Of course, the specific type or subset of NK cells may be more important than total numbers. $\mathrm{NKG} 2 \mathrm{C}+\mathrm{NK}$ cells were shown to specifically respond to and play a crucial role in immunity to cytomegalovirus (Lopez-Verges et al. 2011). However, NKG2C+ NK cells do no expand upon EBV infection (Hendricks et al. 2014). Rather NK cells expressing NKG2A and CD54 could be found in higher numbers in the tonsils of EBV carriers (Lunemann et al. 2013) and in the peripheral blood during acute infection (Hendricks et al. 2014). In a study of pediatric infectious mononucleosis patients, it was recently shown that CD56dim NKG2A + KIR- NK cells preferentially proliferate in response to EBV infected cells during acute infection (Azzi et al. 2014).

EBV also seems to have evolved mechanisms to interfere with the activation of NK cells during viral replication. The protein encoded by the EBV open reading frame BILF1 downregulates expression of HLA-A and HLA-B on the surface of infected cells but not HLA-C, which is inhibitory to NK cells (Griffin et al. 2013). Several specific populations of NK cells have been implicated in limiting the transformation of B cells by EBV in vitro. When exposed to dendritic cells (DCs) prepared with EBV, CD56bright CD16- NK cells were preferentially primed and were able to limit B cell transformation in vitro in an interferon (IFN) $\gamma$ dependent manner. Interestingly, tonsillar NK cells were much more efficient than NK cells derived from peripheral blood (Ferlazzo et al. 2004; Strowig et al. 2008). Further understanding of NK cell recognition of EBV infected cells and their responses during human infection are needed at this point.

Despite our growing understanding of the innate and adaptive immune response to EBV, it remains unclear why primary EBV infection leads to infectious mononucleosis in adolescents yet is most often asymptomatic in young children. It is possible that adolescents receive a larger initial virus inoculum when transmission occurs through deep kissing. Our data did not find any correlation between virus copy number in the oral cavity and severity of illness (Balfour et al. 2013), however peak virus copy number in the oral cavity may not directly reflect the initial virus inoculum, nor is it possible to measure the initial virus inoculum with natural infection. Another idea put forward is that infectious mononucleosis in adolescents may reflect the response of cross-reactive memory CD8 T cells. For example influenza specific CD8+ T cells might cross-react with EBV (Clute et al. 2005) and as adolescents are presumably more likely to have high numbers of influenza specific CD8+ T cells, they could react more strongly with EBV. However, we have not seen evidence of influenza-EBV dual specific CD8+ T cells in our cohort (Odumade et al. 2012) and it remains debatable whether pre-existing (cross-reactive) CD8+ T cell immunity to EBV would increase or decrease infectious mononucleosis. A CD8+ T cell peptide epitope vaccine was effective in generating EBV specific CD8+ T cell responses, and there was no incidence of infectious mononucleosis in the vaccinated group, although the study was small (Burrows et al. 1990). An exciting proposition has arisen from recent data that implicate an NKG2A+ NK cell as important in EBV control (Azzi et al. 2014; Hendricks et al. 2014). Azzi and colleagues showed that CD56dim NKG1A+ KIR- NK cells were found at significantly lower levels in the peripheral blood of adolescents and adults compared to children, suggesting that decreased NK mediated immune control of EBV could explain why adolescents and adults experience infectious mononucleosis more frequently than children. 


\subsection{Convalescence}

During the convalescent period of infectious mononucleosis ( 3 to 6 months postinfection), the number of CD8+ T cells declines to normal levels (Balfour et al. 2013). Previous work in mouse suggested that infection with hepesviruses may cause long term changes to the "readiness" of host immune cells, thus priming them for subsequent bacterial infections (Barton et al. 2007). These effects were later shown to be transient in that model (Yager et al. 2009), but work in human subjects showed that there were no long-term gene expression changes observable in peripheral blood mononuclear cells following acquisition of EBV (Dunmire et al. 2014). The virus is maintained in resting memory-like B cells. Probably the most interesting phenomenon that occurs during this phase of infection is related to the levels of antibody that are produced and maintained by latently infected hosts.

Some peculiar trends exist in the antibody response to EBV. For example, antibodies against EBNA-1 display an unusually long delay between virus acquisition and the presence of antiEBNA-1 IgG, as it generally appears only after a patient with infectious mononucleosis has convalesced (Henle et al. 1987; Hille et al. 1993). This is especially odd given the high levels of class switched antibody toward EBV antigens that can be measured in many patients presenting with infectious mononucleosis, including responses to latently expressed gene products of EBNA-2 and EBNA-3 (Long et al. 2013) (Figures 1 and 2). The delayed kinetic might be associated with alanine-glycine rich regions within the structure of EBNA-1's protein product, which has been shown to inhibit proteosomal processing of relevant epitopes (Levitskaya et al. 1997). That this is the case, however, is not clear and may have to do more with accumulation of protein released from cells for cross presentation. In contrast, high levels of antibody specific for the immediate early antigen BZLF1 are maintained for the life of the host. This is likely because BZLF1 is expressed by cells undergoing viral reactivation and thus is more frequently presented to B cells in latently infected hosts in comparison to proteins that are coded for later in the viral replication process (Massa et al. 2007).

\section{Diagnosis of Infectious Mononucleosis Due to EBV}

Infectious mononucleosis due to EBV should be suspected in patients, especially teenagers and young adults, who present with an acute illness characterized by sore throat, cervical lymphadenopathy, fever and fatigue. Clinical signs that make the diagnosis more likely are exudative pharyngitis with swelling of the uvula and tonsils; periorbital and eyelid edema; and symmetrical cervical and postauricular lymphadenopathy.

A heterophile test using one of number of commercially available antibody kits is most often done to support the clinical diagnosis (Table 5.1). Heterophile tests are relatively inexpensive and easy to perform. However, heterophile antibodies by definition are not specific. They are IgM class antibodies directed against mammalian erythrocytes. False positive heterophile tests have been reported in a myriad of conditions including other acute infections, autoimmune disease, and cancer (Sadoff and Goldsmith 1971; Phillips 1972; Horwitz et al. 1979; Hendry and Longmore 1982; Fisher and Bhalara 2004). Although heterophile tests are most commonly used to diagnose infectious mononucleosis, the U.S. Centers for Disease Control and Prevention has recently advised against them "for general 
use" because of their non-specificity and the possibility of false negative results especially in young children (Centers for Disease Control and Prevention 2014). In our experience, however, if the clinical picture is typical of infectious mononucleosis and the heterophile antibody test is positive, no additional diagnostic procedures are necessary.

No single antibody test is perfect for confirming the diagnosis of primary EBV infection. Most patients (75\%) will have VCA IgM antibodies at the onset of clinical illness and 95\% eventually make them (Table 5.1). In prospective studies of EBV-naïve college students, we detected VCA IgM by EIA as early as 8 days before onset of symptoms. The median first day of detection was 2 days after onset of illness (Figure 1). However, a problem with IgM class antibody tests in general is cross-reactivity with related pathogens. In the case of VCA IgM antibodies, false positive results have been reported especially with cytomegalovirus infections (Guerrero-Ramos et al. 2014).

Depending on the assay platform and antigen used in the assay, VCA IgG antibodies are first detected during the first month of illness. IgG class antibody against the p18 component of VCA develops later than against the p23 component (see Figure 2). Using an EIA with p18 as the antigen, we found in prospective studies that the median first day of detection after onset of illness was 31 with a very wide range of 1-118 days. Everyone who experiences a primary EBV infection develops IgG antibodies to VCA (Balfour et al. 2013), so this is the best single test to verify a previous EBV infection. It is superior to EBNA-1 antibody tests because 5-10\% of patients never make EBNA-1 antibodies. Trends in viral load and antibody titer are shown in figures 1 and 2.

Antibodies against EBNA-1 are slow to appear with a median first day of detection of 91 days (Figure 1). Because of this, the presence of EBNA-1 antibodies during an acute illness rules out primary EBV infection. In general, the vast majority of EBV infections in immunocompetent patients can be staged by assaying a blood sample for VCA IgM, VCA IgG and EBNA-1 antibodies and interpreting the results as shown in Table 5.2. Western blots or immunoblots can be used to confirm results of screening tests and also stage EBV infections (Schubert et al. 1998; Bauer 2001).

Measurement of IgG antibodies against EBV early antigen (EA) are not useful for the diagnosis of primary infection because only $60-80 \%$ of acutely ill patients are positive and EA antibodies can be found for years in $20 \%$ of healthy individuals (Hess 2004; Centers for Disease Control and Prevention 2014). When the available antibody data do not distinguish the stage of an EBV infection, IgG avidity assays may be useful (Schubert et al. 1998; Nystad and Myrmel 2007). The principle is that during the course of infection, antibodies with high binding strength to their target are selected. In other words, IgG antibodies during the acute phase of infection do not bind to their target as tightly as antibodies produced during convalescence. Low avidity antibodies can be dissociated from their target by exposure to urea or another chaotropic reagent. Avidity is determined by comparing the amount of antibody detected with and without urea treatment.

The best test for diagnosing and monitoring EBV infections in the immunocompromised host is the blood viral load (or quantitative EBV DNAemia assay) usually performed on a 
PCR platform (Holman et al. 2012). Most of these infections are not primary but there are a few that are and result in classic infectious mononucleosis. The monitoring concept is to anticipate the risk of impending EBV disease based on sequential changes in blood viral load. A threshold amount, which varies from center to center, is established that triggers intervention with changes in immunosuppressive and/or antiviral drug regimens.

\section{Genetic susceptibility}

Given the disparities in antibody prevalence among populations of different racial backgrounds observed in surveys of children in the United States, there may exist variances in the genetic susceptibility of certain race/ethnicities to EBV. This theory is supported by the incidence of infectious mononucleosis in family groups. A study examining infectious mononucleosis concordance in twins from the California Twin Program found monozygotic twins were twice as likely to both develop infectious mononucleosis than dizygotic twin pairs. When the analysis was limited to same sex dizygotic twins, the risk in those groups was higher (Hwang et al. 2012). These findings were then further expanded to include firstdegree relatives in a large study of Danish families surveyed by governmental registries. The rate ratios for same sex twins were highest, followed by groups of siblings (Rostgaard et al. 2014). It is important to note that siblings tend to have similar environments and behaviors, which may explain why the degree of concordance is so high.

Further evidence lends credence to a genetic basis for susceptibility to infectious mononucleosis. Recently, the HLA locus was identified as a major factor influencing antibodies to EBNA-1 in large Mexican American families (Rubicz et al. 2013). Although the authors interpreted this genetic influence on susceptibility to EBV infection, not all individuals who are infected with EBV make a strong antibody response to EBNA-1. Therefore it is possible that the HLA locus influences the response to infection rather than the infection rate per se. In regard to infectious mononucleosis, the effect on adaptive response to primary infection may be sufficient to achieve a change in whether or not primary infection is symptomatic. Class II MHC is also required for viral entry into the cell, although whether or not there are alterations in viral entry efficiency between HLAs prevalent in different racial groups has not been explored.

\section{Prevention of Primary EBV Infection}

Given the disease burden associated with acute and chronic EBV diseases, development of an EBV vaccine has long been a priority for researchers in the field. The National Cancer Institute recommended that more clinical trials be conducted to test the safety and efficacy of a vaccine to prevent infectious mononucleosis and cancers caused by EBV (Cohen et al. 2011).

Although the first phase 1 trial for a prophylactic EBV vaccine occurred almost twenty years ago (Gu et al. 1995), there has been relatively little progress since. In total, three prophylactic vaccines have been tested in humans, and although all proved at least moderately immunogenic, none provided sterilizing immunity (Balfour 2014). However, sterilizing immunity is probably not necessary to impact symptomatic disease caused by primary EBV infection. For example, a phase 2 trial in Belgium showed that vaccination 
with a gp350 subunit adjuvanted vaccine could reduce the number of cases of infectious mononucleosis (Sokal et al. 2007).

Whether or not a vaccine exclusively targeting gp350 is sufficient to prevent EBV related disease, however, is unknown. In the case of epithelial neoplasia, it seems less convincing on the grounds that gp350 is not strictly required for viral entry into epithelial cells and can be achieved via the viral proteins $\mathrm{gH}$ and gL, albeit less efficiently (Hutt-Fletcher 2007). Increasing the range of the vaccine to include other proteins necessary for this entry such as the aforementioned $\mathrm{gH}$ or gL, especially given what is known concerning the switch tropism of EBV between B cells and epithelial cells, might greatly improve the efficacy of a vaccine with the goal of preventing EBV positive lymphomas and carcinomas.

\section{Treatment}

There is no currently accepted specific treatment for infectious mononucleosis. While it is clear that acyclovir and valacyclovir and have an antiviral effect in vivo, a clinical benefit has not been convincingly demonstrated to date (Tynell et al. 1996). Ganciclovir and valganciclovir have been used treat EBV infections in immunocompromised hosts but there are no controlled trials demonstrating clinical efficacy. Corticosteroids are often prescribed to treat inflammatory complications such as airway obstruction or autoimmune phenomena such as anemia and thrombocytopenia, but the value of these drugs is controversial and they may impair clearance of the viral load (Luzuriaga and Sullivan 2010).

\section{Animal Models of Infectious Mononucleosis}

\subsection{Humanized mice}

One of the major barriers to studying many human viruses is the lack of a small animal model. EBV belongs in this group because it only infects primates. Although studies have been performed with murine gammaherpesvirus-68 (MHV-68) there are important genetic differences between that virus and EBV. In order to directly evaluate the effects of EBV on various lymphoid compartments in vivo, efforts toward developing feasible methods for modeling human infections have resulted in the creation of humanized mice. Humanized mice have only become a viable option for studying human diseases within the last ten years or so due to low engraftment of human cells even in animals with severe combined immunodeficiency (SCID) or knockout of one of the recombinase activating genes (RAG). With the advent of common gamma chain (a receptor component for IL-2, 4, 7, 9, 15, and 21) knockouts, engraftment improved dramatically.

The two types of mice most commonly employed are the previously mentioned NSG and the BALB/c RAG-/- $\gamma \mathrm{c}-/$. . Cells derived from either human fetal liver, human fetal thymus, or CD34+ hematopoietic stem cells are then transferred into neonatal mice to reconstitute their immune systems (Leung et al. 2013). Of these two mouse strains, the NSG mouse has more complete reconstitution of the $\mathrm{T}$ and NK compartments and could be maintained for 22 weeks with latent virus detectable and without developing tumors or other EBV related pathology (Strowig et al. 2009). This model has also been shown to give an approximation of human immune components (Strowig et al. 2010; Ramer et al. 2011). Mice are bred onto 
a transgenic HLA background. This then allows for thymic selection of the human derived cells and later specific responses during infection of these animals with EBV (Yajima et al. 2008; Shultz et al. 2010). It is important to note, however, that study of EBV within this context may neglect important aspects of interplay between EBV and epithelial cells, which have been shown to be important during the replication of EBV, chiefly within the oropharynx (Borza and Hutt-Fletcher 2002). Nevertheless, humanized mice represent a significant step forward to investigating cellular responses in vivo.

In particular, the roles of certain subsets of cells have been interrogated through the depletion of these populations prior to infection with EBV. A significant gap in our understanding of the early innate response to EBV existed and had only been addressed in vitro prior to the advent of this model. Using the NSG mouse and virus obtained from the B95-8 cell line, investigators can now effectively emulate events that occur early during infection in the peripheral blood. Humanized mice exhibit classical features of infectious mononucleosis such as elevated CD8 counts and high levels of IFN $\gamma$ (Chijioke et al. 2013). Specific deletion of subsets of NK cells could then be performed to examine which were most important during the response to primary EBV infection. Furthermore, the roles of adaptive immune cells may be examined as well. Investigators looking at CD4 and CD8 T cells found EBV specific T cells were HLA restricted and responded to autologous lymphoblastioid cell lines. When either CD4 or CD8 T cells were depleted from these mice they developed EBV related pathologies (Strowig et al. 2009). These results are not particularly surprising given the same might be observed in primary human immunodeficiencies as previously described, but provided important evidence that the humanized mouse can be an appropriate tool for asking questions about the response to EBV. Mouse models, however, neglect nearly all aspects of initial infection as events in the oral cavity cannot occur as EBV does not have tropism for murine epithelial cells. In order to examine infection of the tonsil and oral epithelium, primate models might be preferred as there is established infection in the oral cavity similar to EBV in humans.

\subsection{Rabbits}

Studies from Japan have suggested that EBV infection may be modeled in rabbits (Takashima et al. 2008; Okuno et al. 2010). Animals in these studies were alternately inoculated intravenously, intranasally, and perorally with EBV derived from the B95-8 cell line. Most animals had only transient levels of virus detectable in the blood, but two had consistent viral titers. Both $\mathrm{T}$ and $\mathrm{B}$ cells appeared to be infected in these incidences (Takashima et al. 2008; Okuno et al. 2010). It is important to note that while early antigen IgG titers were maintained, $\mathrm{VCA}$ IgG antibodies were transient even when very high quantities of virus were used (Okuno et al. 2010). Though not a model of infection with a great deal of similarity to infectious mononucleosis, rabbits may still provide interesting insight with regard to the kinetics and magnitude of antibody responses to EBV, which has implications for the development and testing of humoral component vaccines such as the gp350 subunit vaccine. 


\subsection{Non-Human Primates}

Non-human primates are the other major option for investigating EBV infection in vivo. The gamma herpes virus lymphocryptovirus (LCV) exists in two types: that which infects old world and new world primates. The LCV that infects old world primates has higher genetic similarity to EBV than new world LCV. The open reading frames of rhesus LCV have 28$98 \%$ amino acid identity with EBV (Wang 2013). Thus, rhesus LCV is used to model EBV in rhesus macaques. The symptoms of EBV and LCV are very similar, and LCV can be given orally to emulate natural infection routes in humans. One difference is that the incubation period of LCV is generally shorter, lasting about three weeks rather than six.

LCV can be manipulated using a bacterial artificial chromosome system to allow for mutation of the LCV genome. This enables researchers to examine the possible effects of EBV homologues in vivo. For example, BARF-1 has been shown to bind and inhibit the signaling of colony stimulating factor 1 (Elegheert et al. 2012; Shim et al. 2012), which can promote the maturation and maintenance of type I interferon producing plasmacytoid DCs (Fancke et al. 2008). Knocking out BARF-1 in LCV resulted in more favorable outcomes and lower viral loads in infected rhesus macaques (Ohashi et al. 2012).

The LCV model can also be used to test potential prophylactic or therapeutic vaccines. An LCV gp350 subunit vaccine protected against infection and reduced the viral set point in rhesus macaques (Sashihara et al. 2011). More recently, Leskowitz and colleagues showed that an adenovirus based vaccine encoding LCV EBNA-1 induced expansion of CD4+ and CD8+ T cells specific for EBNA-1 in rhesus macaques with natural persistent LCV infection (Leskowitz et al. 2014).

\section{Summary and Outlook}

EBV is one of the most important human pathogens. Although this virus was discovered more than 50 years ago and infects more than $90 \%$ of the worldwide population, there are large gaps in our knowledge of its epidemiology and pathogenesis. Our future challenge is to focus research on the following five gaps.

1. We don't know how EBV is transmitted to young children.

2. We don't know why some adolescents and young adults become very ill from a primary EBV infection while others remain completely asymptomatic.

3. We don't have an approved specific treatment for EBV infections.

4. We don't have an approved EBV vaccine.

5. Finally, we don't know the mechanism by which EBV induces malignancies or autoimmune diseases. In terms of EBV-associated cancer, we do know a reasonable amount about how this virus infects and transforms lymphocytes and epithelial cells. What we don't understand is how these cells escape immune recognition. 


\section{Abbreviations}

$\begin{array}{ll}\text { CAEBV } & \text { Chronic active Epstein-Barr virus } \\ \text { DC } & \text { Dendritic cells } \\ \text { EBNA } & \text { Epstein-Barr nuclear antigen } \\ \text { EBV } & \text { Epstein-Barr virus } \\ \text { eBL } & \text { Endemic Burkitt's lymphoma } \\ \text { EIA } & \text { Enzyme immunoassay } \\ \text { HL } & \text { Hodgkin's lymphoma } \\ \text { HLA } & \text { Human leukocyte antigen } \\ \text { HLH } & \text { Hemophagocytic lymphohistiocytosis } \\ \text { IFN } & \text { Interferon } \\ \text { LCV } & \text { Lymphocryptovirus } \\ \text { MHC } & \text { Major histocompatability complex } \\ \text { MS } & \text { Multiple sclerosis } \\ \text { NK } & \text { Natural killer } \\ \text { NHANES } & \text { National Health and Nutrition Examination Survey } \\ \text { NIH } & \text { National Institutes of Health } \\ \text { NPC } & \text { Nasopharyngeal carcinoma } \\ \text { SAP } & \text { Signaling lymphocytic activation molecule associated protein } \\ \text { VCA } & \text { Viral capsid antigen } \\ \text { XLP } & \text { X-linked lymphoproliferative disease }\end{array}$

\section{References}

Abbott RJ, Quinn LL, Leese AM, Scholes HM, Pachnio A, Rickinson AB. CD8+ T cell responses to lytic EBV infection: late antigen specificities as subdominant components of the total response. J Immunol. 2013; 191:5398-5409.10.4049/jimmunol.1301629 [PubMed: 24146041]

Adhikary D, Behrends U, Boerschmann H, Pfunder A, Burdach S, Moosmann A, Witter K, Bornkamm GW, Mautner J. Immunodominance of lytic cycle antigens in Epstein-Barr virus-specific CD4+ T cell preparations for therapy. PLoS One. 2007; 2:e583.10.1371/journal.pone.0000583 [PubMed: 17611619]

Alotaibi S, Kennedy J, Tellier R, Stephens D, Banwell B. Epstein-Barr virus in pediatric multiple sclerosis. JAMA. 2004; 291:1875-1879.10.1001/jama.291.15.1875 [PubMed: 15100207]

Ascherio A, Munger KL. Epstein-barr virus infection and multiple sclerosis: a review. J Neuroimmune Pharmacol. 2010; 5:271-277.10.1007/s11481-010-9201-3 [PubMed: 20369303]

Azzi T, Lunemann A, Murer A, Ueda S, Beziat V, Malmberg KJ, Staubli G, Gysin C, Berger C, Munz C, Chijioke O, Nadal D. Role for early-differentiated natural killer cells in infectious mononucleosis. Blood. 2014; 124:2533-2543.10.1182/blood-2014-01-553024 [PubMed: 25205117]

Balfour HH Jr. Progress, prospects, and problems in Epstein-Barr virus vaccine development. Curr Opin Virol. 2014; 6C:1-5.10.1016/j.coviro.2014.02.005 [PubMed: 24632197] 
Balfour HH Jr, Forte FA, Simpson RB, Zolov DM. Penicillin-related exanthems in infectious mononucleosis identical to those associated with ampicillin. Clin Pediatr. 1972; 11:417-421.

Balfour HH Jr, Odumade OA, Schmeling DO, Mullan BD, Ed JA, Knight JA, Vezina HE, Thomas W, Hogquist KA. Behavioral, virologic, and immunologic factors associated with acquisition and severity of primary Epstein-Barr virus infection in university students. J Infect Dis. 2013; 207:8088.10.1093/infdis/jis646 [PubMed: 23100562]

Balfour HH Jr, Sifakis F, Sliman JA, Knight JA, Schmeling DO, Thomas W. Age-specific prevalence of Epstein-Barr virus infection among individuals aged 6-19 years in the United States and factors affecting its acquisition. J Infect Dis. 2013; 208:1286-1293.10.1093/infdis/jit321 [PubMed: 23868878]

Banwell B, Krupp L, Kennedy J, Tellier R, Tenembaum S, Ness J, Belman A, Boiko A, Bykova O, Waubant E, Mah JK, Stoian C, Kremenchutzky M, Bardini MR, Ruggieri M, Rensel M, Hahn J, Weinstock-Guttman B, Yeh EA, Farrell K, Freedman M, Iivanainen M, Sevon M, Bhan V, Dilenge ME, Stephens D, Bar-Or A. Clinical features and viral serologies in children with multiple sclerosis: a multinational observational study. Lancet Neurol. 2007; 6:773-781.10.1016/ S1474-4422(07)70196-5 [PubMed: 17689148]

Barton ES, White DW, Cathelyn JS, Brett-McClellan KA, Engle M, Diamond MS, Miller VL, Virgin HW. Herpesvirus latency confers symbiotic protection from bacterial infection. Nature. 2007; 447:326-329.10.1038/nature05762 [PubMed: 17507983]

Bauer G. Simplicity through complexity: immunoblot with recombinant antigens as the new gold standard in Epstein-Barr virus serology. Clin Lab. 2001; 47:223-230. [PubMed: 11405600]

Beutel K, Gross-Wieltsch U, Wiesel T, Stadt UZ, Janka G, Wagner HJ. Infection of T lymphocytes in Epstein-Barr virus-associated hemophagocytic lymphohistiocytosis in children of non-Asian origin. Pediatr Blood Cancer. 2009; 53:184-190.10.1002/pbc.22037 [PubMed: 19353621]

Blake N, Haigh T, Shaka'a G, Croom-Carter D, Rickinson A. The importance of exogenous antigen in priming the human CD8+ T cell response: lessons from the EBV nuclear antigen EBNA1. J Immunol. 2000; 165:7078-7087. [PubMed: 11120837]

Borza CM, Hutt-Fletcher LM. Alternate replication in B cells and epithelial cells switches tropism of Epstein-Barr virus. Nat Med. 2002; 8:594-599.10.1038/nm0602-594 [PubMed: 12042810]

Brady G, MacArthur GJ, Farrell PJ. Epstein-Barr virus and Burkitt lymphoma. J Clin Pathol. 2007; 60:1397-1402.10.1136/jcp.2007.047977 [PubMed: 18042696]

Burrows SR, Sculley TB, Misko IS, Schmidt C, Moss DJ. An Epstein-Barr virus-specific cytotoxic T cell epitope in EBV nuclear antigen 3 (EBNA 3). J Exp Med. 1990; 171:345-349. [PubMed: 1688611]

Cannons JL, Tangye SG, Schwartzberg PL. SLAM family receptors and SAP adaptors in immunity. Annu Rev Immunol. 2011; 29:665-705.10.1146/annurev-immunol-030409-101302 [PubMed: 21219180]

Chijioke O, Muller A, Feederle R, Barros MH, Krieg C, Emmel V, Marcenaro E, Leung CS, Antsiferova O, Landtwing V, Bossart W, Moretta A, Hassan R, Boyman O, Niedobitek G, Delecluse HJ, Capaul R, Munz C. Human natural killer cells prevent infectious mononucleosis features by targeting lytic Epstein-Barr virus infection. Cell Rep. 2013; 5:1489-1498.10.1016/ j.celrep.2013.11.041 [PubMed: 24360958]

Clute SC, Watkin LB, Cornberg M, Naumov YN, Sullivan JL, Luzuriaga K, Welsh RM, Selin LK. Cross-reactive influenza virus-specific CD8+ T cells contribute to lymphoproliferation in EpsteinBarr virus-associated infectious mononucleosis. J Clin Invest. 2005; 115:3602-3612.10.1172/ JCI25078 [PubMed: 16308574]

Cohen JI, Fauci AS, Varmus H, Nabel GJ. Epstein-Barr virus: an important vaccine target for cancer prevention. Sci Transl Med. 2011; 3:107fs107.10.1126/scitranslmed.3002878

Cohen JI, Jaffe ES, Dale JK, Pittaluga S, Heslop HE, Rooney CM, Gottschalk S, Bollard CM, Rao VK, Marques A, Burbelo PD, Turk SP, Fulton R, Wayne AS, Little RF, Cairo MS, El-Mallawany NK, Fowler D, Sportes C, Bishop MR, Wilson W, Straus SE. Characterization and treatment of chronic active Epstein-Barr virus disease: a 28-year experience in the United States. Blood. 2011; 117:5835-5849.10.1182/blood-2010-11-316745 [PubMed: 21454450] 
Condon LM, Cederberg LE, Rabinovitch MD, Liebo RV, Go JC, Delaney AS, Schmeling DO, Thomas W, Balfour HH Jr. Age-Specific Prevalence of Epstein-Barr Virus Infection among Minnesota Children Effects of Race/Ethnicity and Family Environment. Clin Infect Dis. 201410.1093/cid/ciu342

Connelly KP, DeWitt LD. Neurologic complications of infectious mononucleosis. Pediatr Neurol. 1994; 10:181-184. [PubMed: 8060419]

Crawford DH, Macsween KF, Higgins CD, Thomas R, McAulay K, Williams H, Harrison N, Reid S, Conacher M, Douglas J, Swerdlow AJ. A cohort study among university students: identification of risk factors for Epstein-Barr virus seroconversion and infectious mononucleosis. Clin Infect Dis. 2006; 43:276-282.10.1086/505400 [PubMed: 16804839]

Crowcroft NS, Vyse A, Brown DW, Strachan DP. Epidemiology of Epstein-Barr virus infection in pre-adolescent children: application of a new salivary method in Edinburgh, Scotland. J Epidemiol Community Health. 1998; 52:101-104. [PubMed: 9578856]

de-The G, Day NE, Geser A, Lavoue MF, Ho JH, Simons MJ, Sohier R, Tukei P, Vonka V, Zavadova H. Sero-epidemiology of the Epstein-Barr virus: preliminary analysis of an international study - a review. IARC Sci Publ. 1975:3-16. [PubMed: 191375]

de-The G, Geser A, Day NE, Tukei PM, Williams EH, Beri DP, Smith PG, Dean AG, Bronkamm GW, Feorino P, Henle W. Epidemiological evidence for causal relationship between Epstein-Barr virus and Burkitt's lymphoma from Ugandan prospective study. Nature. 1978; 274:756-761. [PubMed: 210392]

Downey HM, CA. Acute lymphadenosis compared with acute lymphatic leukemia. Arch Intern Med. $1923 ; 32: 82-112$.

Dunmire SK, Odumade OA, Porter JL, Reyes-Genere J, Schmeling DO, Bilgic H, Fan D, Baechler EC, Balfour HH Jr, Hogquist KA. Primary EBV infection induces an expression profile distinct from other viruses but similar to hemophagocytic syndromes. PLoS One. 2014; 9:e85422.10.1371/ journal.pone.0085422 [PubMed: 24465555]

Elegheert J, Bracke N, Pouliot P, Gutsche I, Shkumatov AV, Tarbouriech N, Verstraete K, Bekaert A, Burmeister WP, Svergun DI, Lambrecht BN, Vergauwen B, Savvides SN. Allosteric competitive inactivation of hematopoietic CSF-1 signaling by the viral decoy receptor BARF1. Nat Struct Mol Biol. 2012; 19:938-947.10.1038/nsmb.2367 [PubMed: 22902366]

Fancke B, Suter M, Hochrein H, O'Keeffe M. M-CSF: a novel plasmacytoid and conventional dendritic cell poietin. Blood. 2008; 111:150-159.10.1182/blood-2007-05-089292 [PubMed: 17916748]

Ferlazzo G, Pack M, Thomas D, Paludan C, Schmid D, Strowig T, Bougras G, Muller WA, Moretta L, Munz C. Distinct roles of IL-12 and IL-15 in human natural killer cell activation by dendritic cells from secondary lymphoid organs. Proc Natl Acad Sci U S A. 2004; 101:16606-16611.10.1073/ pnas.0407522101 [PubMed: 15536127]

Figueira-Silva CM, Pereira FE. Prevalence of Epstein-Barr virus antibodies in healthy children and adolescents in Vitoria, State of Espirito Santo, Brazil. Rev Soc Bras Med Trop. 2004; 37:409-412. S0037-86822004000500008. [PubMed: 15361959]

Fisher BA, Bhalara S. False-positive result provided by rapid heterophile antibody test in a case of acute infection with hepatitis E virus. J Clin Microbiol. 2004; 42:4411.10.1128/JCM. 42.9.4411.2004 [PubMed: 15365060]

Flavell KJ, Murray PG. Hodgkin's disease and the Epstein-Barr virus. Mol Pathol. 2000; 53:262-269. [PubMed: 11091850]

Gerber P, Walsh JH, Rosenblum EN, Purcell RH. Association of EB-virus infection with the postperfusion syndrome. Lancet. 1969; 1:593-595. [PubMed: 4180127]

Griffin BD, Gram AM, Mulder A, Van Leeuwen D, Claas FH, Wang F, Ressing ME, Wiertz E. EBV BILF1 evolved to downregulate cell surface display of a wide range of HLA class I molecules through their cytoplasmic tail. J Immunol. 2013; 190:1672-1684.10.4049/jimmunol.1102462 [PubMed: 23315076]

Gu SY, Huang TM, Ruan L, Miao YH, Lu H, Chu CM, Motz M, Wolf H. First EBV vaccine trial in humans using recombinant vaccinia virus expressing the major membrane antigen. Dev Biol Stand. 1995; 84:171-177. [PubMed: 7796951] 
Guerrero-Ramos A, Patel M, Kadakia K, Haque T. Performance of the architect EBV antibody panel for determination of Epstein-Barr virus infection stage in immunocompetent adolescents and young adults with clinical suspicion of infectious mononucleosis. Clin Vaccine Immunol. 2014; 21:817-823.10.1128/CVI.00754-13 [PubMed: 24695777]

Hadinoto V, Shapiro M, Greenough TC, Sullivan JL, Luzuriaga K, Thorley-Lawson DA. On the dynamics of acute EBV infection and the pathogenesis of infectious mononucleosis. Blood. 2008; 111:1420-1427.10.1182/blood-2007-06-093278 [PubMed: 17991806]

Hanto DW, Frizzera G, Purtilo DT, Sakamoto K, Sullivan JL, Saemundsen AK, Klein G, Simmons RL, Najarian JS. Clinical spectrum of lymphoproliferative disorders in renal transplant recipients and evidence for the role of Epstein-Barr virus. Cancer Res. 1981; 41:4253-4261. [PubMed: 6272971]

Hendricks DW, Balfour HH Jr, Dunmire SK, Schmeling DO, Hogquist KA, Lanier LL. Cutting Edge: NKG2ChiCD57+ NK Cells Respond Specifically to Acute Infection with Cytomegalovirus and Not Epstein-Barr Virus. J Immunol. 201410.4049/jimmunol.1303211

Hendry BM, Longmore JM. Systemic lupus erythematosus presenting as infectious mononucleosis with a false positive monospot test. Lancet. 1982; 1:455. [PubMed: 6121125]

Henle G, Henle W, Clifford P, Diehl V, Kafuko GW, Kirya BG, Klein G, Morrow RH, Munube GM, Pike P, Tukei PM, Ziegler JL. Antibodies to Epstein-Barr virus in Burkitt's lymphoma and control groups. J Natl Cancer Inst. 1969; 43:1147-1157. [PubMed: 5353242]

Henle W, Henle G, Andersson J, Ernberg I, Klein G, Horwitz CA, Marklund G, Rymo L, Wellinder C, Straus SE. Antibody responses to Epstein-Barr virus-determined nuclear antigen (EBNA)-1 and EBNA-2 in acute and chronic Epstein-Barr virus infection. Proc Natl Acad Sci U S A. 1987; 84:570-574. [PubMed: 3025881]

Hess RD. Routine Epstein-Barr virus diagnostics from the laboratory perspective: still challenging after 35 years. J Clin Microbiol. 2004; 42:3381-3387.10.1128/JCM.42.8.3381-3387.2004 [PubMed: 15297472]

Hesse J, Ibsen KK, Krabbe S, Uldall P. Prevalence of antibodies to Epstein-Barr virus (EBV) in childhood and adolescence in Denmark. Scand J Infect Dis. 1983; 15:335-338. [PubMed: 6318303]

Hille A, Klein K, Baumler S, Grasser FA, Mueller-Lantzsch N. Expression of Epstein-Barr virus nuclear antigen 1,2A and 2B in the baculovirus expression system: serological evaluation of human antibodies to these proteins. J Med Virol. 1993; 39:233-241. [PubMed: 8385705]

Hislop AD, Palendira U, Leese AM, Arkwright PD, Rohrlich PS, Tangye SG, Gaspar HB, Lankester AC, Moretta A, Rickinson AB. Impaired Epstein-Barr virus-specific CD8+ T-cell function in Xlinked lymphoproliferative disease is restricted to SLAM family-positive B-cell targets. Blood. 2010; 116:3249-3257.10.1182/blood-2009-09-238832 [PubMed: 20644117]

Hislop AD, Taylor GS, Sauce D, Rickinson AB. Cellular responses to viral infection in humans: lessons from Epstein-Barr virus. Annu Rev Immunol. 2007; 25:587-617.10.1146/ annurev.immunol.25.022106.141553 [PubMed: 17378764]

Hjalgrim H, Askling J, Sorensen P, Madsen M, Rosdahl N, Storm HH, Hamilton-Dutoit S, Eriksen LS, Frisch M, Ekbom A, Melbye M. Risk of Hodgkin's disease and other cancers after infectious mononucleosis. J Natl Cancer Inst. 2000; 92:1522-1528. [PubMed: 10995808]

Hjalgrim, H.; Friborg, J.; Melbye, M. The epidemiology of EBV and its association with malignant disease. In: Arvin, A., et al., editors. Human Herpesviruses: Biology, Therapy, and Immunoprophylaxis. Cambridge: 2007.

Hoagland RJ. The transmission of infectious mononucleosis. Am J Med Sci. 1955; 229:262-272. [PubMed: 14349955]

Hoagland RJ, Henson HM. Splenic rupture in infectious mononucleosis. Ann Intern Med. 1957; 46:1184-1191. [PubMed: 13435667]

Holman CJ, Karger AB, Mullan BD, Brundage RC, Balfour HH Jr. Quantitative Epstein-Barr virus shedding and its correlation with the risk of post-transplant lymphoproliferative disorder. Clin Transplant. 2012; 26:741-747.10.1111/j.1399-0012.2012.01608.x [PubMed: 22385033]

Horwitz CA, Henle W, Henle G, Goldfarb M, Kubic P, Gehrz RC, Balfour HH Jr, Fleisher GR, Krivit W. Clinical and laboratory evaluation of infants and children with Epstein-Barr virus-induced 
infectious mononucleosis: report of 32 patients (aged 10-48 months). Blood. 1981; 57:933-938. [PubMed: 6260269]

Horwitz CA, Henle W, Henle G, Penn G, Hoffman N, Ward PC. Persistent falsely positive rapid tests for infectious mononucleosis. Report of five cases with four--six-year follow-up data. Am J Clin Pathol. 1979; 72:807-811. [PubMed: 228546]

Hutt-Fletcher LM. Epstein-Barr virus entry. J Virol. 2007; 81:7825-7832.10.1128/JVI.00445-07 [PubMed: 17459936]

Hwang AE, Hamilton AS, Cockburn MG, Ambinder R, Zadnick J, Brown EE, Mack TM, Cozen W. Evidence of genetic susceptibility to infectious mononucleosis: a twin study. Epidemiol Infect. 2012; 140:2089-2095.10.1017/S0950268811002457 [PubMed: 22152594]

Iizasa H, Nanbo A, Nishikawa J, Jinushi M, Yoshiyama H. Epstein-Barr Virus (EBV)-associated gastric carcinoma. Viruses. 2012; 4:3420-3439. [PubMed: 23342366]

Janka GE. Familial and acquired hemophagocytic lymphohistiocytosis. Annu Rev Med. 2012; 63:233246.10.1146/annurev-med-041610-134208 [PubMed: 22248322]

Jenson HB. Acute complications of Epstein-Barr virus infectious mononucleosis. Curr Opin Pediatr. 2000; 12:263-268. [PubMed: 10836164]

Jordan MB, Allen CE, Weitzman S, Filipovich AH, McClain KL. How I treat hemophagocytic lymphohistiocytosis. Blood. 2011; 118:4041-4052.10.1182/blood-2011-03-278127 [PubMed: 21828139]

Kawaguchi H, Miyashita T, Herbst H, Niedobitek G, Asada M, Tsuchida M, Hanada R, Kinoshita A, Sakurai M, Kobayashi N, et al. Epstein-Barr virus-infected T lymphocytes in Epstein-Barr virusassociated hemophagocytic syndrome. J Clin Invest. 1993; 92:1444-1450.10.1172/JCI116721 [PubMed: 8397226]

Kimura H, Hoshino Y, Kanegane H, Tsuge I, Okamura T, Kawa K, Morishima T. Clinical and virologic characteristics of chronic active Epstein-Barr virus infection. Blood. 2001; 98:280-286. [PubMed: 11435294]

Kimura H, Morishima T, Kanegane H, Ohga S, Hoshino Y, Maeda A, Imai S, Okano M, Morio T, Yokota S, Tsuchiya S, Yachie A, Imashuku S, Kawa K, Wakiguchi H. Japanese Association for Research on Epstein-Barr V, Related D. Prognostic factors for chronic active Epstein-Barr virus infection. J Infect Dis. 2003; 187:527-533.10.1086/367988 [PubMed: 12599068]

Krabbe S, Hesse J, Uldall P. Primary Epstein-Barr virus infection in early childhood. Arch Dis Child. 1981; 56:49-52. [PubMed: 6258487]

Lang DJ, Garruto RM, Gajdusek DC. Early acquisition of cytomegalovirus and Epstein-Barr virus antibody in several isolated Melanesian populations. Am J Epidemiol. 1977; 105:480-487. [PubMed: 193397]

Leskowitz R, Fogg MH, Zhou XY, Kaur A, Silveira EL, Villinger F, Lieberman PM, Wang F, Ertl HC. Adenovirus-based vaccines against rhesus lymphocryptovirus EBNA-1 induce expansion of specific CD8+ and CD4+ T cells in persistently infected rhesus macaques. J Virol. 2014; 88:47214735.10.1128/JVI.03744-13 [PubMed: 24522914]

Leung C, Chijioke O, Gujer C, Chatterjee B, Antsiferova O, Landtwing V, McHugh D, Raykova A, Munz C. Infectious diseases in humanized mice. Eur J Immunol. 2013; 43:2246-2254.10.1002/eji. 201343815 [PubMed: 23913412]

Levin LI, Munger KL, O’Reilly EJ, Falk KI, Ascherio A. Primary infection with the Epstein-Barr virus and risk of multiple sclerosis. Ann Neurol. 2010; 67:824-830.10.1002/ana.21978 [PubMed: 20517945]

Levitskaya J, Sharipo A, Leonchiks A, Ciechanover A, Masucci MG. Inhibition of ubiquitin/ proteasome-dependent protein degradation by the Gly-Ala repeat domain of the Epstein-Barr virus nuclear antigen 1. Proc Natl Acad Sci U S A. 1997; 94:12616-12621. [PubMed: 9356498]

Long HM, Chagoury OL, Leese AM, Ryan GB, James E, Morton LT, Abbott RJ, Sabbah S, Kwok W, Rickinson AB. MHC II tetramers visualize human CD4+ T cell responses to Epstein-Barr virus infection and demonstrate atypical kinetics of the nuclear antigen EBNA1 response. J Exp Med. 2013; 210:933-949.10.1084/jem.20121437 [PubMed: 23569328]

Lopez-Verges S, Milush JM, Schwartz BS, Pando MJ, Jarjoura J, York VA, Houchins JP, Miller S, Kang SM, Norris PJ, Nixon DF, Lanier LL. Expansion of a unique CD57(+)NKG2Chi natural 
killer cell subset during acute human cytomegalovirus infection. Proc Natl Acad Sci U S A. 2011; 108:14725-14732.10.1073/pnas.1110900108 [PubMed: 21825173]

Lunemann A, Vanoaica LD, Azzi T, Nadal D, Munz C. A distinct subpopulation of human NK cells restricts B cell transformation by EBV. J Immunol. 2013; 191:4989-4995.10.4049/jimmunol. 1301046 [PubMed: 24108698]

Luzuriaga K, Sullivan JL. Infectious mononucleosis. N Engl J Med. 2010; 362:1993-2000.10.1056/ NEJMcp1001116 [PubMed: 20505178]

Massa J, Munger KL, O'Reilly EJ, Falk KI, Ascherio A. Plasma titers of antibodies against EpsteinBarr virus BZLF1 and risk of multiple sclerosis. Neuroepidemiology. 2007; 28:214215.10.1159/000108113 [PubMed: 17851260]

Melbye M, Ebbesen P, Levine PH, Bennike T. Early primary infection and high Epstein-Barr virus antibody titers in Greenland Eskimos at high risk for nasopharyngeal carcinoma. Int J Cancer. 1984; 34:619-623. [PubMed: 6094363]

Menasche G, Feldmann J, Fischer A, de Saint Basile G. Primary hemophagocytic syndromes point to a direct link between lymphocyte cytotoxicity and homeostasis. Immunol Rev. 2005; 203:165179.10.1111/j.0105-2896.2005.00224.x [PubMed: 15661029]

Merlo A, Turrini R, Trento C, Zanovello P, Dolcetti R, Rosato A. Impact of gamma-chain cytokines on EBV-specific T cell cultures. J Transl Med. 2010; 8:121.10.1186/1479-5876-8-121 [PubMed: 21092174]

Morris MC, Edmunds WJ. The changing epidemiology of infectious mononucleosis? J Infect. 2002; 45:107-109. S0163445302910224 [pii]. [PubMed: 12217713]

Nystad TW, Myrmel H. Prevalence of primary versus reactivated Epstein-Barr virus infection in patients with VCA IgG-, VCA IgM- and EBNA-1-antibodies and suspected infectious mononucleosis. J Clin Virol. 2007; 38:292-297.10.1016/j.jcv.2007.01.006 [PubMed: 17336144]

Odumade OA, Hogquist KA, Balfour HH Jr. Progress and problems in understanding and managing primary Epstein-Barr virus infections. Clin Microbiol Rev. 2011; 24:193-209.10.1128/cmr. 00044-10 [PubMed: 21233512]

Odumade OA, Knight JA, Schmeling DO, Masopust D, Balfour HH Jr, Hogquist KA. Primary Epstein-Barr virus infection does not erode preexisting CD8(+) T cell memory in humans. J Exp Med. 2012; 209:471-478.10.1084/jem.20112401 [PubMed: 22393125]

Ohashi M, Fogg MH, Orlova N, Quink C, Wang F. An Epstein-Barr virus encoded inhibitor of Colony Stimulating Factor-1 signaling is an important determinant for acute and persistent EBV infection. PLoS Pathog. 2012; 8:e1003095.10.1371/journal.ppat.1003095 [PubMed: 23300447]

Okuno K, Takashima K, Kanai K, Ohashi M, Hyuga R, Sugihara H, Kuwamoto S, Kato M, Sano H, Sairenji T, Kanzaki S, Hayashi K. Epstein-Barr virus can infect rabbits by the intranasal or peroral route: an animal model for natural primary EBV infection in humans. J Med Virol. 2010; 82:977986.10.1002/jmv.21597 [PubMed: 20419811]

Pakpoor J, Disanto G, Gerber JE, Dobson R, Meier UC, Giovannoni G, Ramagopalan SV. The risk of developing multiple sclerosis in individuals seronegative for Epstein-Barr virus: a meta-analysis. Mult Scler. 2013; 19:162-166.10.1177/1352458512449682 [PubMed: 22740437]

Palendira U, Low C, Chan A, Hislop AD, Ho E, Phan TG, Deenick E, Cook MC, Riminton DS, Choo S, Loh R, Alvaro F, Booth C, Gaspar HB, Moretta A, Khanna R, Rickinson AB, Tangye SG. Molecular pathogenesis of EBV susceptibility in XLP as revealed by analysis of female carriers with heterozygous expression of SAP. PLoS Biol. 2011; 9:e1001187.10.1371/journal.pbio. 1001187 [PubMed: 22069374]

Pappworth IY, Wang EC, Rowe M. The switch from latent to productive infection in epstein-barr virus-infected B cells is associated with sensitization to NK cell killing. J Virol. 2007; 81:474482.10.1128/JVI.01777-06 [PubMed: 17079298]

Parvaneh N, Filipovich AH, Borkhardt A. Primary immunodeficiencies predisposed to Epstein-Barr virus-driven haematological diseases. Br J Haematol. 2013; 162:573-586.10.1111/bjh.12422 [PubMed: 23758097]

Pathmanathan R, Prasad U, Sadler R, Flynn K, Raab-Traub N. Clonal proliferations of cells infected with Epstein-Barr virus in preinvasive lesions related to nasopharyngeal carcinoma. N Engl J Med. 1995; 333:693-698.10.1056/NEJM199509143331103 [PubMed: 7637746] 
Pender MP, Csurhes PA, Smith C, Beagley L, Hooper KD, Raj M, Coulthard A, Burrows SR, Khanna R. Epstein-Barr virus-specific adoptive immunotherapy for progressive multiple sclerosis. Mult Scler. 201410.1177/1352458514521888

Phillips GM. False-positive monospot test result in rubella. JAMA. 1972; 222:585. [PubMed: 4678104]

Piriou E, Asito AS, Sumba PO, Fiore N, Middeldorp JM, Moormann AM, Ploutz-Snyder R, Rochford R. Early age at time of primary Epstein-Barr virus infection results in poorly controlled viral infection in infants from Western Kenya: clues to the etiology of endemic Burkitt lymphoma. $\mathrm{J}$ Infect Dis. 2012; 205:906-913.10.1093/infdis/jir872 [PubMed: 22301635]

Pohl D, Krone B, Rostasy K, Kahler E, Brunner E, Lehnert M, Wagner HJ, Gartner J, Hanefeld F. High seroprevalence of Epstein-Barr virus in children with multiple sclerosis. Neurology. 2006; 67:2063-2065.10.1212/01.wnl.0000247665.94088.8d [PubMed: 17159123]

Centers for Disease Control and Prevention. Epstein-Barr virus and infectious mononucleosis. Centers for Disease Control and Prevention; 2014. http://www.cdc.gov/epstein-barr/laboratory-testing.html [Accessed 08 Aug 2014 2014]

Putukian M, O’Connor FG, Stricker P, McGrew C, Hosey RG, Gordon SM, Kinderknecht J, Kriss V, Landry G. Mononucleosis and athletic participation: an evidence-based subject review. Clin J Sport Med. 2008; 18:309-315.10.1097/JSM.0b013e31817e34f8 [PubMed: 18614881]

Quintanilla-Martinez L, Kumar S, Fend F, Reyes E, Teruya-Feldstein J, Kingma DW, Sorbara L, Raffeld M, Straus SE, Jaffe ES. Fulminant EBV(+) T-cell lymphoproliferative disorder following acute/chronic EBV infection: a distinct clinicopathologic syndrome. Blood. 2000; 96:443-451. [PubMed: 10887104]

Raab-Traub N. Epstein-Barr virus in the pathogenesis of NPC. Semin Cancer Biol. 2002; 12:431-441. [PubMed: 12450729]

Raab-Traub N, Flynn K. The structure of the termini of the Epstein-Barr virus as a marker of clonal cellular proliferation. Cell. 1986; 47:883-889. [PubMed: 3022942]

Ramer PC, Chijioke O, Meixlsperger S, Leung CS, Munz C. Mice with human immune system components as in vivo models for infections with human pathogens. Immunol Cell Biol. 2011; 89:408-416.10.1038/icb.2010.151 [PubMed: 21301484]

Rigaud S, Fondaneche MC, Lambert N, Pasquier B, Mateo V, Soulas P, Galicier L, Le Deist F, RieuxLaucat F, Revy P, Fischer A, de Saint Basile G, Latour S. XIAP deficiency in humans causes an X-linked lymphoproliferative syndrome. Nature. 2006; 444:110-114.10.1038/nature05257 [PubMed: 17080092]

Robinson RG. Abdominal complications of infectious mononucleosis. J Am Board Fam Pract. 1988; 1:207-210. [PubMed: 3051895]

Rostgaard K, Wohlfahrt J, Hjalgrim H. A genetic basis for infectious mononucleosis: Evidence from a family study of hospitalized cases in Denmark. Clin Infect Dis. 201410.1093/cid/ciu204

Rubicz R, Yolken R, Drigalenko E, Carless MA, Dyer TD, Bauman L, Melton PE, Kent JW Jr, Harley JB, Curran JE, Johnson MP, Cole SA, Almasy L, Moses EK, Dhurandhar NV, Kraig E, Blangero J, Leach CT, Goring HH. A genome-wide integrative genomic study localizes genetic factors influencing antibodies against Epstein-Barr virus nuclear antigen 1 (EBNA-1). PLoS Genet. 2013; 9:e1003147.10.1371/journal.pgen.1003147 [PubMed: 23326239]

Sadoff L, Goldsmith O. False-positive infectious mononucleosis spot test in pancreatic carcinoma. JAMA. 1971; 218:1297-1298. [PubMed: 5171178]

Sashihara J, Hoshino Y, Bowman JJ, Krogmann T, Burbelo PD, Coffield VM, Kamrud K, Cohen JI. Soluble rhesus lymphocryptovirus gp350 protects against infection and reduces viral loads in animals that become infected with virus after challenge. PLoS Pathog. 2011; 7:e1002308.10.1371/journal.ppat.1002308 [PubMed: 22028652]

Schooley RT, Carey RW, Miller G, Henle W, Eastman R, Mark EJ, Kenyon K, Wheeler EO, Rubin RH. Chronic Epstein-Barr virus infection associated with fever and interstitial pneumonitis. Clinical and serologic features and response to antiviral chemotherapy. Ann Intern Med. 1986; 104:636-643. [PubMed: 3008616] 
Schubert J, Zens W, Weissbrich B. Comparative evaluation of the use of immunoblots and of IgG avidity assays as confirmatory tests for the diagnosis of acute EBV infections. J Clin Virol. 1998; 11:161-172. [PubMed: 9949952]

Shapiro RS, McClain K, Frizzera G, Gajl-Peczalska KJ, Kersey JH, Blazar BR, Arthur DC, Patton DF, Greenberg JS, Burke B, et al. Epstein-Barr virus associated B cell lymphoproliferative disorders following bone marrow transplantation. Blood. 1988; 71:1234-1243. [PubMed: 2833957]

Shim AH, Chang RA, Chen X, Longnecker R, He X. Multipronged attenuation of macrophage-colony stimulating factor signaling by Epstein-Barr virus BARF1. Proc Natl Acad Sci U S A. 2012; 109:12962-12967.10.1073/pnas.1205309109 [PubMed: 22826234]

Shultz LD, Saito Y, Najima Y, Tanaka S, Ochi T, Tomizawa M, Doi T, Sone A, Suzuki N, Fujiwara H, Yasukawa M, Ishikawa F. Generation of functional human T-cell subsets with HLA-restricted immune responses in HLA class I expressing NOD/SCID/IL2r gamma(null) humanized mice. Proc Natl Acad Sci U S A. 2010; 107:13022-13027.10.1073/pnas.1000475107 [PubMed: 20615947]

Slyker JA, Casper C, Tapia K, Richardson B, Bunts L, Huang ML, Maleche-Obimbo E, Nduati R, John-Stewart G. Clinical and virologic manifestations of primary Epstein-Barr virus (EBV) infection in Kenyan infants born to HIV-infected women. J Infect Dis. 2013; 207:17981806.10.1093/infdis/jit093 [PubMed: 23493724]

Sokal EM, Hoppenbrouwers K, Vandermeulen C, Moutschen M, Leonard P, Moreels A, Haumont M, Bollen A, Smets F, Denis M. Recombinant gp350 vaccine for infectious mononucleosis: a phase 2, randomized, double-blind, placebo-controlled trial to evaluate the safety, immunogenicity, and efficacy of an Epstein-Barr virus vaccine in healthy young adults. J Infect Dis. 2007; 196:1749_ 1753.10.1086/523813 [PubMed: 18190254]

Sprunt TPE, FA. Mononuclear leucocytosis in reaction to acute infections ("infectious mononucleosis"). Johns Hopkins Hosp Bull. 1920; 31:410-417.

Strautins K, Tschochner M, James I, Choo L, Dunn DS, Pedrini M, Kermode A, Carroll W, Nolan D. Combining HLA-DR risk alleles and anti-Epstein-Barr virus antibody profiles to stratify multiple sclerosis risk. Mult Scler. 2014; 20:286-294.10.1177/1352458513498829 [PubMed: 23886832]

Strowig T, Brilot F, Arrey F, Bougras G, Thomas D, Muller WA, Munz C. Tonsilar NK cells restrict B cell transformation by the Epstein-Barr virus via IFN-gamma. PLoS Pathog. 2008; 4:e27.10.1371/journal.ppat.0040027 [PubMed: 18266470]

Strowig T, Chijioke O, Carrega P, Arrey F, Meixlsperger S, Ramer PC, Ferlazzo G, Munz C. Human NK cells of mice with reconstituted human immune system components require preactivation to acquire functional competence. Blood. 2010; 116:4158-4167.10.1182/blood-2010-02-270678 [PubMed: 20671122]

Strowig T, Gurer C, Ploss A, Liu YF, Arrey F, Sashihara J, Koo G, Rice CM, Young JW, Chadburn A, Cohen JI, Munz C. Priming of protective T cell responses against virus-induced tumors in mice with human immune system components. J Exp Med. 2009; 206:1423-1434.10.1084/jem. 20081720 [PubMed: 19487422]

Sumaya CV, Ench Y. Epstein-Barr virus infections in families: the role of children with infectious mononucleosis. J Infect Dis. 1986; 154:842-850. [PubMed: 3021867]

Sumaya CV, Henle W, Henle G, Smith MH, LeBlanc D. Seroepidemiologic study of Epstein-Barr virus infections in a rural community. J Infect Dis. 1975; 131:403-408. [PubMed: 163869]

Svedmyr E, Ernberg I, Seeley J, Weiland O, Masucci G, Tsukuda K, Szigeti R, Masucci MG, Blomogren H, Berthold W. Virologic, immunologic, and clinical observations on a patient during the incubation, acute, and convalescent phases of infectious mononucleosis. Clin Immunol Immunopathol. 1984; 30:437-450. [PubMed: 6199144]

Takashima K, Ohashi M, Kitamura Y, Ando K, Nagashima K, Sugihara H, Okuno K, Sairenji T, Hayashi K. A new animal model for primary and persistent Epstein-Barr virus infection: human EBV-infected rabbit characteristics determined using sequential imaging and pathological analysis. J Med Virol. 2008; 80:455-466.10.1002/jmv.21102 [PubMed: 18205213]

Takeuchi K, Tanaka-Taya K, Kazuyama Y, Ito YM, Hashimoto S, Fukayama M, Mori S. Prevalence of Epstein-Barr virus in Japan: trends and future prediction. Pathol Int. 2006; 56:112116.10.1111/j.1440-1827.2006.01936.x [PubMed: 16497243] 
Tynell E, Aurelius E, Brandell A, Julander I, Wood M, Yao QY, Rickinson A, Akerlund B, Andersson J. Acyclovir and prednisolone treatment of acute infectious mononucleosis: a multicenter, double-blind, placebo-controlled study. J Infect Dis. 1996; 174:324-331. [PubMed: 8699062]

Venkitaraman AR, Lenoir GM, John TJ. The seroepidemiology of infection due to Epstein-Barr virus in southern India. J Med Virol. 1985; 15:11-16. [PubMed: 2981976]

Wang F. Nonhuman primate models for Epstein-Barr virus infection. Curr Opin Virol. 2013; 3:233237.10.1016/j.coviro.2013.03.003 [PubMed: 23562212]

Wang X, Kenyon WJ, Li Q, Mullberg J, Hutt-Fletcher LM. Epstein-Barr virus uses different complexes of glycoproteins $\mathrm{gH}$ and $\mathrm{gL}$ to infect B lymphocytes and epithelial cells. J Virol. 1998; 72:5552-5558. [PubMed: 9621012]

Warner HB, Carp RI. Multiple sclerosis and Epstein-Barr virus. Lancet. 1981; 2:1290. [PubMed: 6118702]

White LR, Karofsky PS. Review of the clinical manifestations, laboratory findings, and complications of infectious mononucleosis. Wis Med J. 1985; 84:19-25. [PubMed: 3002047]

Williams H, McAulay K, Macsween KF, Gallacher NJ, Higgins CD, Harrison N, Swerdlow AJ, Crawford DH. The immune response to primary EBV infection: a role for natural killer cells. $\mathrm{Br}$ J Haematol. 2005; 129:266-274.10.1111/j.1365-2141.2005.05452.x [PubMed: 15813855]

Yager EJ, Szaba FM, Kummer LW, Lanzer KG, Burkum CE, Smiley ST, Blackman MA. gammaHerpesvirus-induced protection against bacterial infection is transient. Viral Immunol. 2009; 22:67-72.10.1089/vim.2008.0086 [PubMed: 19210230]

Yajima M, Imadome K, Nakagawa A, Watanabe S, Terashima K, Nakamura H, Ito M, Shimizu N, Honda M, Yamamoto N, Fujiwara S. A new humanized mouse model of Epstein-Barr virus infection that reproduces persistent infection, lymphoproliferative disorder, and cell-mediated and humoral immune responses. J Infect Dis. 2008; 198:673-682.10.1086/590502 [PubMed: 18627269]

Zhao F, Cannons JL, Dutta M, Griffiths GM, Schwartzberg PL. Positive and negative signaling through SLAM receptors regulate synapse organization and thresholds of cytolysis. Immunity. 2012; 36:1003-1016.10.1016/j.immuni.2012.05.017 [PubMed: 22683123] 


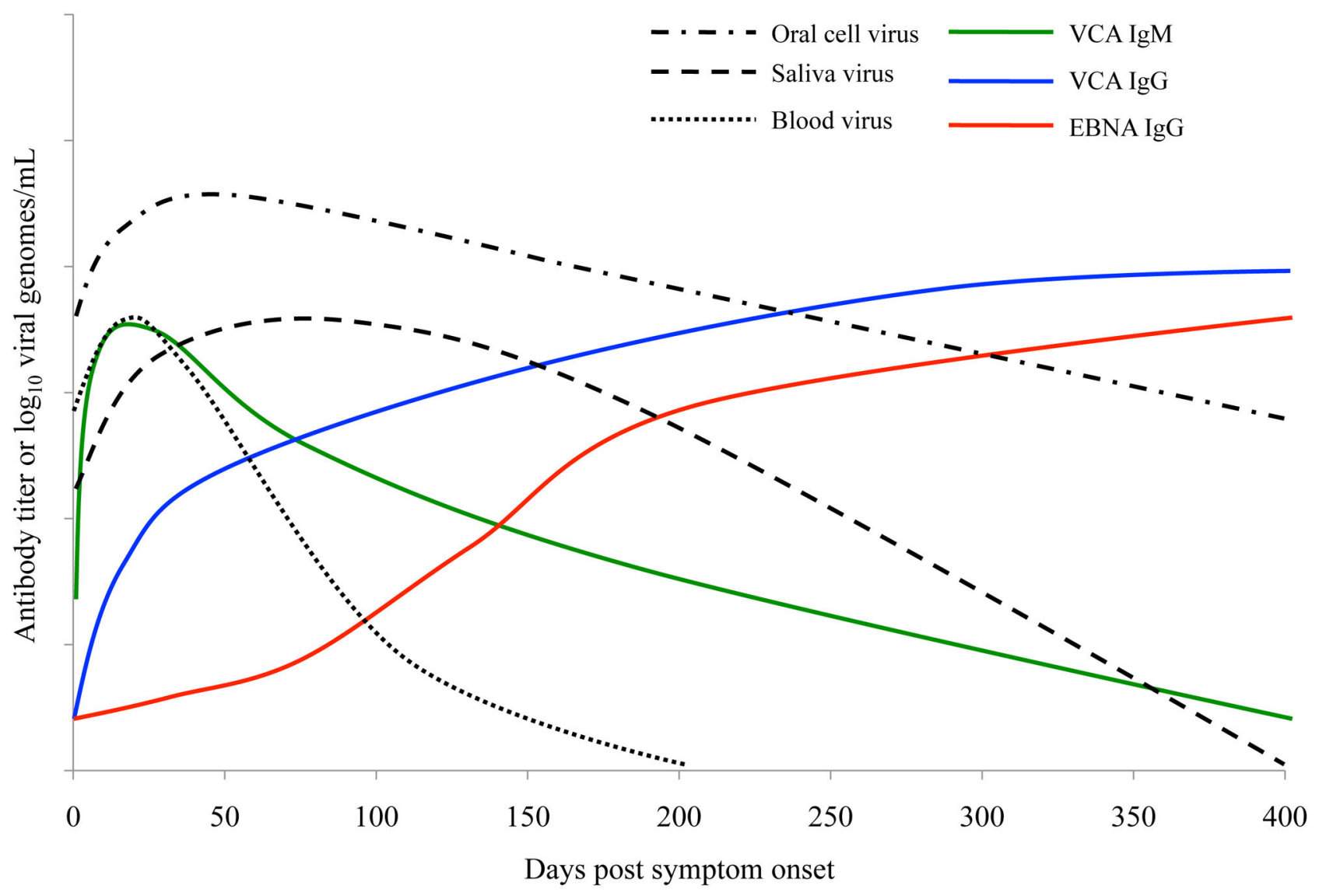

Figure 1. Kinetics of EBV viral load and antibody responses in subjects with primary EBV infection

Depicted are viral loads in whole blood, saliva, and oral cell pellets (black lines) as well as IgM and IgG antibodies to VCA and IgG to EBNA1 (colored lines). Note: the limit of detection of the EBV viral genomes in blood was 200 copies per $\mathrm{mL}$ of whole blood. 


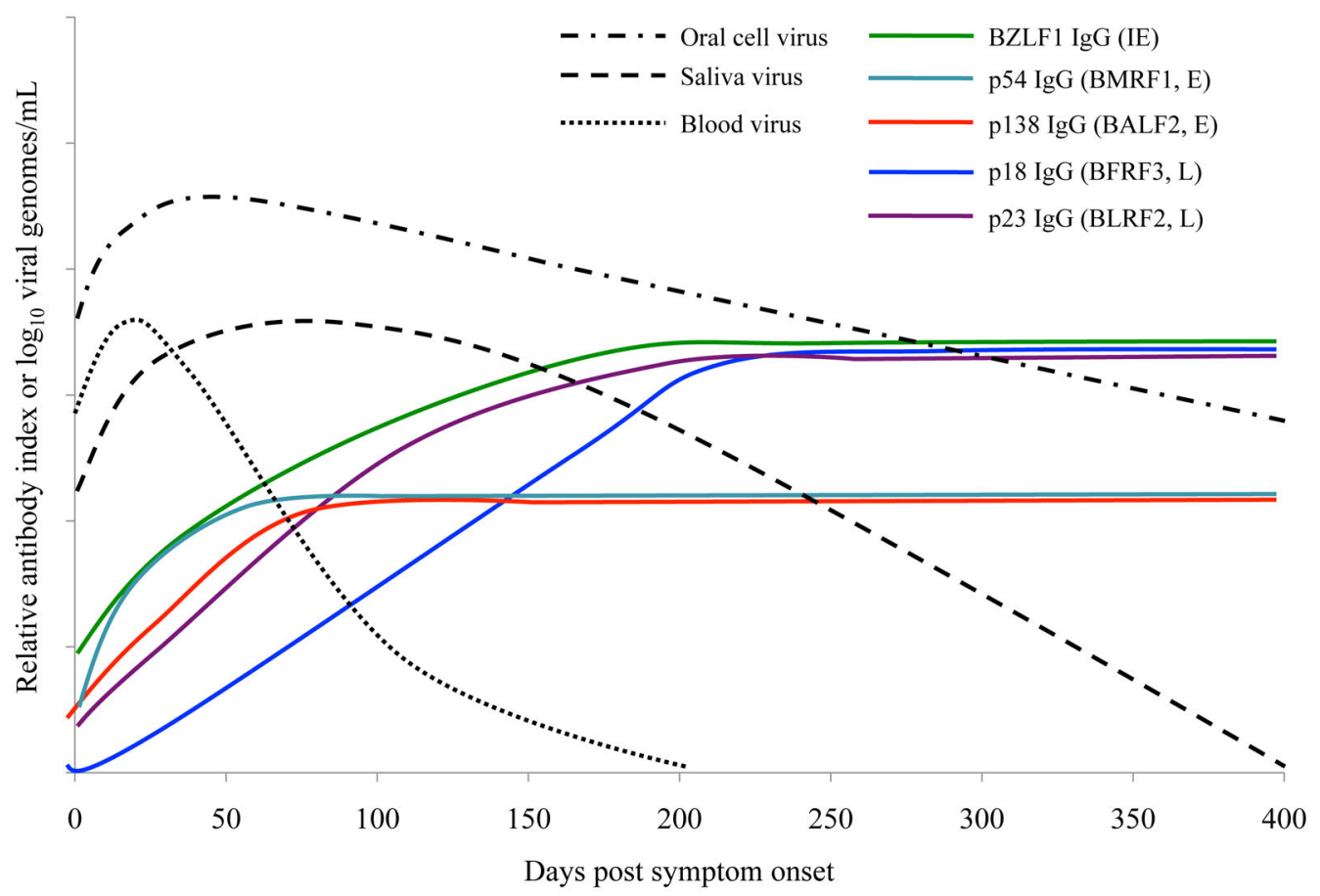

Figure 2. Kinetics of antibody responses to additional EBV antigens as determined by immunoblot

Depicted are viral loads in whole blood, saliva, and oral cell pellets (black lines) as well as the relative kinetics of antibodies generated against the EBV antigens p18, p23, BZLF1, p138, and p54 (colored lines). The gene name of each antigen and the stage of expression (IE: immediate early, E: early, or L: late) are indicated in parentheses. 
Table 3.1

Clinical features of primary EBV infections in 72 undergraduate students studied prospectively (48 women, 24 men; age range, 18-22 years)

\begin{tabular}{|l|c|c|}
\hline Feature & No. of Subjects (\%) & Median Duration (Days) \\
\hline Sore Throat & $68(94 \%)$ & 10 \\
\hline Cervical Lymphadenopathy & $58(81 \%)$ & 21 \\
\hline Fatigue & $52(72 \%)$ & 20 \\
\hline Upper Respiratory Symptoms & $46(64 \%)$ & 4.5 \\
\hline Headache & $38(53 \%)$ & 9.5 \\
\hline Decreased Appetite & $38(53 \%)$ & 9.5 \\
\hline Feels Feverish & $34(47 \%)$ & 4 \\
\hline Myalgia (Body Aches) & $33(46 \%)$ & 3 \\
\hline
\end{tabular}

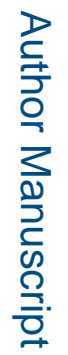

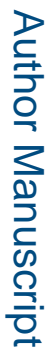


Table 3.2

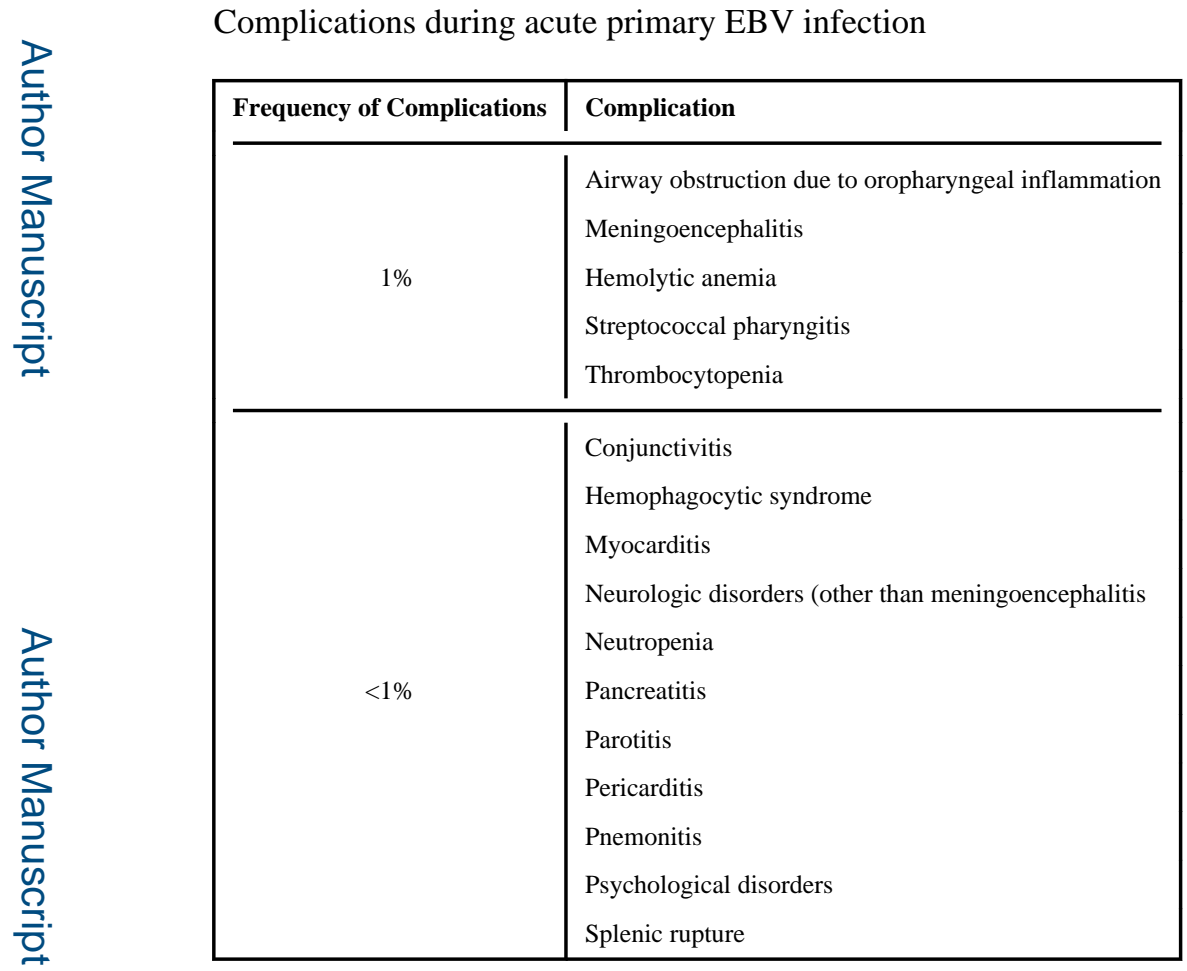


Table 5.1

Staging EBV Infection by enzyme immunoassay patterns

\begin{tabular}{|c|c|c|c|}
\hline Stage of Infection & VCA IgM & VCA IgG & EBNA-1 IgG \\
\hline Naïve & Negative & Negative & Negative \\
\hline Acute Primary $a$ & $1-2+$ & $\mathrm{Neg}-1+$ & Negative \\
\hline Subacute $^{b}$ & $3-4+$ & $2-4+$ & Negative-1+ \\
\hline Convalescent ${ }^{c}$ & Negative $-3+$ & $3-4+$ & Negative-2+ \\
\hline Past $^{d}(90-95 \%$ of cases) & Negative & $3+$ & $3-4+$ \\
\hline Past $^{d}(5-10 \%$ of cases $)$ & Negative & $3+$ & Negative \\
\hline
\end{tabular}

$a_{0}$ to 3 weeks after onset of illness

$b_{3}$ weeks to 3 months after onset of illness

$c_{3}$ to 6 months after onset of illness

$d_{>} 6$ months after onset of illness 
Table 5.2

Diagnostic tests for EBV infections

\begin{tabular}{|c|c|c|c|c|}
\hline Test & Advantages & Disadvantages & $\begin{array}{l}\text { Proportion of } \\
\text { Patients } \\
\text { Positive }^{a}\end{array}$ & $\begin{array}{l}\text { Median Day } \\
\text { Detected after } \\
\text { Onset of } \\
\text { Illness (range } \\
\text { of days until } \\
\text { detection) } a\end{array}$ \\
\hline Heterophile antibody & $\begin{array}{l}\text { Inexpensive, easy to perform, } \\
\text { becomes negative } 3-12 \text { months } \\
\text { postinfection }\end{array}$ & $\begin{array}{l}\text { Nonspecific (false positives due to acute } \\
\text { infections and autoimmune diseases); } \\
\text { may be negative during first week of } \\
\text { illness and persistently negative in } \\
\text { young children } b\end{array}$ & $\begin{array}{l}85 \%(72 \% \text { the } \\
\text { first week) }\end{array}$ & $0(-6-31)$ \\
\hline VCA IgM antibody & $\begin{array}{l}\text { Specific, becomes negative } 3-12 \\
\text { months postinfection }\end{array}$ & $\begin{array}{l}\text { Not usually performed at point of care } \\
\text { sites }\end{array}$ & $\begin{array}{l}95 \%(85 \% \text { the } \\
\text { first week) }\end{array}$ & $2(-21-20)$ \\
\hline VCA IgG antibody & $\begin{array}{l}\text { Best test for diagnosis of past } \\
\text { EBV infection }\end{array}$ & $\begin{array}{l}\text { Not usually performed at point of care } \\
\text { sites }\end{array}$ & $100 \%$ & $31(1-118)$ \\
\hline EBNA-1 IgG antibody & $\begin{array}{l}\text { Best test to distinguish acute from } \\
\text { convalescent EBV infection }\end{array}$ & $\begin{array}{l}\text { Not usually performed at point of care } \\
\text { sites; } 5-10 \% \text { of patients never become } \\
\text { positive }\end{array}$ & $90-95 \%$ & $91(6-479)$ \\
\hline EA antibody & A marker of acute infection & $\begin{array}{l}\text { Absent in } 20-40 \% \text { of acute illnesses; } \\
\text { persists for years in } \sim 20 \% \text { of cases }\end{array}$ & Not tested & Not tested \\
\hline Immunoblot antibodies & $\begin{array}{l}\text { Can be used to stage infection } \\
\text { (acute, convalescent, past) }\end{array}$ & Relatively expensive & $100 \% c$ & $2(-25-60)$ \\
\hline Blood viral load & $\begin{array}{l}\text { Correlates with severity of } \\
\text { illness; best test to monitor } \\
\text { infection in the } \\
\text { immuncompromised host }\end{array}$ & $\begin{array}{l}\text { Viremia is short-lived and may be } \\
\text { missed in immunocompetent patients }\end{array}$ & $80 \%$ & $4(-8-38)$ \\
\hline Oral viral load & $\begin{array}{l}\text { Non-invasive, confirms past } \\
\text { infection }\end{array}$ & $\begin{array}{l}\text { Cannot be used to diagnose acute } \\
\text { infection because virtually all antibody- } \\
\text { positive adults shed oral virus } \\
\text { intermittently }\end{array}$ & $100 \%$ & $-4(-21-31)$ \\
\hline
\end{tabular}

${ }^{a}$ Based on prospective studies of EBV-naive college students who developed primary EBV infections (Balfour et al. 2005; Balfour et al. 2013a; Balfour et al. Unpublished observations.

${ }^{b}$ Although heterophile tests are most commonly used to diagnose infectious mononucleosis, the CDC has recently advised against them "for general use."(Centers for Disease Control and Prevention 2014).

${ }^{c}$ To one or more antigens. 